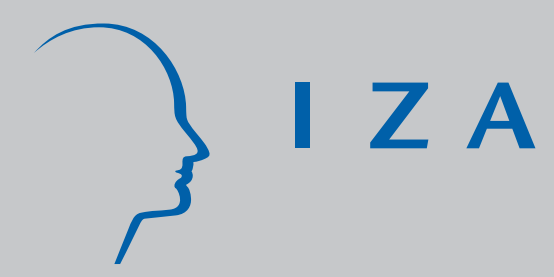

IZADP No. 3779

Crime, Unemployment, and Xenophobia? An Ecological Analysis of Right-Wing Election Results in Hamburg, 1986-2005

Ralph Rotte

Martin Steininger

October 2008 


\title{
Crime, Unemployment, and Xenophobia? An Ecological Analysis of Right-Wing Election Results in Hamburg, 1986-2005
}

\author{
Ralph Rotte \\ RWTH Aachen University \\ and IZA \\ Martin Steininger \\ Munich University of Technology
}
Discussion Paper No. 3779
October 2008

\author{
IZA \\ P.O. Box 7240 \\ 53072 Bonn \\ Germany \\ Phone: +49-228-3894-0 \\ Fax: +49-228-3894-180 \\ E-mail: iza@iza.org
}

\begin{abstract}
Any opinions expressed here are those of the author(s) and not those of IZA. Research published in this series may include views on policy, but the institute itself takes no institutional policy positions.

The Institute for the Study of Labor (IZA) in Bonn is a local and virtual international research center and a place of communication between science, politics and business. IZA is an independent nonprofit organization supported by Deutsche Post World Net. The center is associated with the University of Bonn and offers a stimulating research environment through its international network, workshops and conferences, data service, project support, research visits and doctoral program. IZA engages in (i) original and internationally competitive research in all fields of labor economics, (ii) development of policy concepts, and (iii) dissemination of research results and concepts to the interested public.
\end{abstract}

IZA Discussion Papers often represent preliminary work and are circulated to encourage discussion. Citation of such a paper should account for its provisional character. A revised version may be available directly from the author. 


\section{ABSTRACT \\ Crime, Unemployment, and Xenophobia? An Ecological Analysis of Right-Wing Election Results in Hamburg, 1986-2005}

This paper investigates the consequences of immigration, crime and socio-economic depriviation for the performance of right-wing extremist and populist parties in the German city state of Hamburg between 1986 and 2005. The ecological determinants of voting for right-wing parties on the district level are compared to those for mainstream and other protest parties. Parallels and differences in spatial characteristics between right-wing extremist and populist parties' performance are identified. Our empirical results tend to confirm the general contextual sociological theory of right-wing radicalization by general social deprivation and immigration. Nevertheless they indicate that one has to be very cautious when interpreting the unemployment/crime - right-winger nexus. Moreover, crime does not seem to have a strong significant effect on right-wing populist parties' election successes despite its importance for their programmes and campaigns.

JEL Classification: D60, D72, I28, J60, P16

Keywords: elections, political extremism, labor market policy, welfare policy, immigration

Corresponding author:

Ralph Rotte

Institute of Political Science

RWTH Aachen University

Ahornstrasse 55

52074 Aachen

Germany

E-mail: rotte@ipw.rwth-aachen.de 


\section{Introduction}

Questions like integration strategies for immigrants and approaches to combat crime have been one important focus of election campaigns in Germany since the 1980s. The most recent case is the failure of the incumbent CDU prime minister of Hesse, Roland Koch, in his notorious attempt to mobilize conservative voters by asking for tougher sanctions against criminal youngsters and, more or less implicitly, against criminal immigrants in January 2008. The CDU campaign in Hesse is not the first attempt of 'centre' parties to approach populist structures and content. ${ }^{1}$ Nevertheless, topics like fear of immigration and crime as well as of rising unemployment and social decline of natives remain typical issues in party programmes and campaign strategies of right-wing extremist and populist parties in Germany as well as all over Western Europe.

In this paper we investigate the empirical determinants of right-wing extremist and populist election results in the city state of Hamburg from 1986 to 2005. Since the 1990s, the Bundesland of Hamburg with its special features of a city state and a commercial metropolitan area on the North Sea has become a kind of role model for the rise and fall of parties and movements covering right-wing and/or populist programmes and attitudes. We focus on an ecological analysis of the circumstances facilitating right-wing parties' successes on the district level. Apart from gaining some new insights in the structural foundations of right-wing voting in Hamburg our aim is twofold: First, we want to demonstrate that empirical election analysis based on spatial context data instead of surveys of individuals may make an important contribution to the field of voting behaviour and election studies in general. Second, we wish to provide a scientifically sound empirical basis for democratic policies to counter right-wing extremism.

The paper is organized in seven further sections. Part 2 discusses some terminological aspects of right-wing extremism and populism in the German context. It sketches typical patterns of explanation of this phenomenon in the social science literature. Section 3 gives an overview of the methodological and theoretical problems of ecological election analysis and explains our own approach. Part 4 summarizes the central findings of previous ecological studies of voting results of right-wing parties in Europe on a local level. Section 5 sketches the development and programmes of right-wing extremist and populist parties in Germany and Hamburg. Chapter 6 presents our dataset and statistical method. Section 7 summarizes our empirical findings, and section 8 concludes.

\section{Right-wing extremism and populism}

\section{Some remarks on terminology}

Before we turn to our theoretical and empirical analysis of election results of right-wing parties in Hamburg, we have to deal briefly with the terms "extremism" and "populism". In general one may define political extremism as an anti-constitutional, anti-democratic movement with more or less authoritarian or totalitarian aims based on a somewhat consistent anti-pluralistic ideology. ${ }^{2}$ A modern understanding of political extremism allows for a broad interpretation of these characteristics in order to cover not only neo-Nazi or Stalinist groups and parties but also petty bourgeois, populist protest movements like the French poujadisme. 
Traditionally, left and right-wing extremisms in Europe are mainly distinguished by their Marxist-Leninist or ethnocentric and chauvinist orientations. These result in ideas of fundamental changes of society according to the model of an ideal future community of man or an idealized past with traditional values, respectively. ${ }^{3}$

Modern right-wing extremism is characterized by a mixture of neoliberal and authoritarian aims. It turns against state interventionism in the economy and against the political establishment. It claims to protect the interests of ordinary people and is based on ethnocentric, anti-foreigner and authoritarian views of politics and social interactions. The prototype of such a right-wing extremist party is the French Front National.

Right-wing populist parties emphasizes opposition against the ruling political elites and public order rather than ethnocentric, xenophobic contents. Like their extremist complements they tend to have a strong orientation towards a party leader and strict hierarchies in party organization. Nevertheless, they are less ideologically closed since they try to keep in touch with the volatile mood of the voters in the first place. Typical examples for such right-wing populist parties are the Austrian Liberals (FPÖ) and the Italian Lega Nord. ${ }^{4}$

These theoretical differences between political extremism and populism, however, may be gradual and hardly identifiable in actual day-to-day politics. This is especially important in the case of the so-called "New Right" in Germany. They have been trying to disguise their extremist views by adapting to conservative arguments and habits of intellectual discourse since the early 1990s. Moreover, according to the German authorities, there is a growing number of organizational connections between extremist and populist right-wing parties and groups.

\section{Explanations of right-wing extremism and populism}

What are the main determinants of right-wing extremism and populism mentioned in the social science literature? Basically, if one looks at the various ideological elements of rightwing parties all over Europe, the common denominator of right-wing movements consists of two sets of attributes: (1) a clear distinction between in and out-groups (including ethnocentrism, xenophobia and racism), and (2) a fundamental hierarchical orientation (including a longing for authoritarian government and nationalism). ${ }^{5}$ Previous empirical work on right-wing extremist and populist attitudes and election successes in Europe has found three major sets of determinants explaining right-wing orientations among citizens: ${ }^{6}$ (1) socioeconomic deprivation (e.g. by unemployment or fear of losing one's job), (2) anti-modernist traditionalism (e.g. a very strong belief in law and order, male role models, patriotism and nationalism, obedience to social and political hierarchies or anti-immigration attitudes), and (3) social isolation and low social status (e.g. a low level of education, low income or substandard living conditions).

\section{Problems and merits of ecological election analysis}

\section{Spatial analysis in election studies}

Empirical work on right-wing extremism is mostly based on survey data, i.e. on individual information and self-perception given in interviews. This implies not only standard methodological problems of reliability of revealed preferences and attitudes but also the 
question of practical political consequences. After all, it might be harder for politicians to change immaterial, psychologically driven attitudes than socio-economic conditions people live in. Given that we are interested in determinants of right-wing extremism and populism which may be altered by e.g. economic, social or education policy, we ask for the structural factors driving the political success of extremist parties. As a result we use an "ecological" approach that focuses on the actual socio-economic environment in which voting decisions are taken.

Ecological analyses of election results are far rarer in the literature than papers based on survey data. One reason might be the greater heterogeneity and complexity of data sets combining various resources rather than basically using one survey data set. On the other hand, it is possible to use data provided by official statistics. Therefore such ecological data might be more reliable than results of interviews.

\section{The ecological fallacy problem}

Another point concerns the "ecological fallacy“ problem first elaborated by Robinson in $1950^{7}$. He has shown that it is logically difficult to draw conclusions concerning individual behaviour from aggregated data. Basically, two main problems occur: First, relevant information about individuals is lost by aggregation, and second, regression models using aggregated data are subject to a massive heteroskedasticity problem. As a consequence, traditional simple linear regression results are heavily biased. ${ }^{8}$ This is crucial in the empirical analysis of election results and voting behaviour. For example, one must not conclude from the fact that Democrats in the U.S. win relatively many votes in areas mostly populated by blacks that blacks tend to vote for Democratic candidates rather than for Republicans. According to $\mathrm{King}^{9}$ it is also possible (and empirically sound) to conclude that whites living in areas dominated by black inhabitants have a different voting behaviour than whites in white-dominated areas, and vote more often Democrat than Republican than the latter do. Another example is election successes of the National Socialists in Germany in the early 1930s, especially in 1930, about which there is only aggregated data available ${ }^{10}$. According to conventional wisdom, it was mainly the unemployed of the Great Depression who disproportionally favoured the Nazis. After all, they won especially in labour office districts with high unemployment rates. ${ }^{11}$ Falter $^{12}$, however, has shown that on the county level, there was a clear negative correlation between unemployment and Nazi election successes. This might be explained by fears of still employed but insecure and dissatisfied people who turned away from the established parties to the Nazis promising law and order as well as jobs and job security, while actual unemployed rather turned to the communists.

How have researchers reacted to this fundamental problem of ecological fallacy? Some have more or less neglected the problem ${ }^{13}$ while others have tried to cope with it by using special statistical methods ${ }^{14}$. Others have totally turned down the idea of ecological analysis. ${ }^{15}$ As a general methodological rule is seems established wisdom now to avoid it, at least if microdata is available. We accept this as a general rule of thumb. Nevertheless, we also see the problem that this attitude to empirical social science tends to neglect potentially important aspects of political processes related to spatial dimensions, i.e. the environmental and social framework of political behaviour. As Gary King has put it: “The literature's nearly exclusive focus on [...] surveys with random interviews of isolated individuals means that the geographic component to social science data is often neglected. [...] If 'all politics is local,' political science is missing much of politics."16 
We therefore think that ecological analysis is sensible in our case. First, we try to cope with the heteroskedasticity bias by applying a statistical method which has been designed for data situations in which unobserved heterogeneity spoils any attempt to sensibly use traditional linear regression models. Moreover, in interpreting our empirical results we concentrate on the statistical significance of the estimated parameters instead of their magnitude. After all, right-wing parties still receive relatively small shares of the vote which is why even small coefficients may indicate important determinants of their election success (or failure, for that matter), if only they differ significantly from zero. Moreover, virtually all of the literature in empirical political science so far has dealt with biased ecological coefficient estimates leading to implausible or impossible predictions, like voter turnouts exceeding 100 percent. Significance of the ecological parameter estimates, however, has not been a topic, especially since in the critical examples, even the simplest statistical techniques typically result in qualitatively reliable information on the coefficients' significance despite important differences in their magnitude. ${ }^{17}$

Second, the aggregation bias is explicitly addressed by our research question. Following the normative aspect of our analysis, we do not intend to draw any direct conclusions about individual decision-making processes and attitudes from our empirical findings. As mentioned above we are mostly interested in identifiying structural socio-economic conditions that drive right-wing extremism and populism, which may be changed by political activity. Political activity, however, can hardly try to influence each voter's individual convictions but has to rely on changes in the structures in which individuals take their decisions. In other words, since political measures mainly aim at aggregate conditions it makes sense to analyze the very structural framework that might be altered in order to fight right-wing parties. After all, it has been emphasized in the discussion about Nazi election successes in the 1930, that "Hitler would have come to power even if not a single unemployed had actually voted for him." ${ }^{18}$ Thus, it is not an individual's attitudes and worldviews motivating him or her to vote for right-wing parties which we are interested in, but the local conditions this voting decision is made in.

\section{Connecting individual behaviour and aggregate data}

What then remains is a logical problem of the theoretical foundation underlying any expected correlation of electoral success and socio-economic conditions in an area. All of the three explanatory hypotheses from the literature mentioned above are (at least in part) about individual-level-relationships, and not solely about contextual effects. For instance, the second hypothesis about anti-modernist traditionalism states that males and the elderly people tend to have traditionalist attitudes, and not that the age structure of the macro unit (the district) has a direct effect. Certainly, it is plausible that for most determinants of right-wing voting, there are both individual level and macro level effects (e.g. both the unemployment rate in a district and the employment status of an individual have an effect on right-wing voting). Nevertheless, the basic logical problem remains: How can aggregate effects on voting output be explained when we cannot necessarily rely on individual decision-making processes?

The solution for this logical problem is provided by two points. First, as the example of Nazi election successes has demonstrated, ecological factors may have different ways of influencing individual decision-making. Nevertheless, the positive effect of unemployment on the NSDAP share of the vote persists, no matter if it was the unemployed themselves who voted for Hitler, or employed feeling threatened by prospects of unemployment or other 
people feeling occupational insecurity. Our macro-oriented research question remains open for alternative micro-explanations of the transmission of ecological circumstances into invidual behaviour. Since our aim is not to verify or falsify any mictro-theory of voting, we do not have any problem to settle with such a reduced form approach to the problem.

Moreover, there is also a more elegant way to reconcile individual-level explanations of voting behaviour with aggregate-level evidence by choosing a specific context-oriented view of voting. "Contextual theories of political behavior generally characterize how individuals respond to their social environment. They recognize that individuals view political life through different lenses depending upon the communities they inhabit. People experience different pressures and face different incentives because of where they happen to reside. [...] aggregate statistics summarize the social environment shaping political behavior. They portray many of the external incentives and pressures that operate on political actors, especially those bound by geography." "As a consequence, "sociotropic" theories of voting stress the importance of the general macro-context of a situation for the individual's voting behaviour. Therefore, as more recent empirical work ${ }^{20}$ has shown, it might not only be the traditional "pocket book" aspects that count in voting but, even more importantly, any aspect concerning one's position in society and life that drives individual behaviour.

In fact, strictly individual and context-related aspects of perception of one's situation, let alone behaviour, may be two inseparable sides of one coin. A recent paper on the causes of fear of crime, for example, has demonstrated that individual fear of crime in Hamburg varies significantly across city districts, and is determined by individual as well as contextual variables. $^{21}$ Thus, in the case of voting behaviour, similar aggregate framework conditions of individual life might play a significant role. This gives us some strong theoretical justification for the ecological approach even if we accept the basic ecological fallacy problem.

\section{Previous findings of ecological election analyses on the local level}

Our expectations concerning the results of our empirical study are also shaped by the findings of previous ecological election analyses on the local level. A detailed multiple regression analysis of municipal elections in Belgium in $1988^{22}$, for example, has revealed that average income was positively related to the Liberals' share of the vote and negatively to the Christian Democrats' and Socialists'. Socialists performed well in communities with a high number of welfare recipients, while a high share of college graduates in the population reduced their result and increased the Greens' vote. Communities with a high share of young inhabitants tended to vote for Christian Democrats or Greens; a more elderly population improved the turnout for Socialists, Liberals and the Vlaams Blok. Socialists, Greens and Vlaams Blok won in city centers, Christian Democrats in the countryside. High numbers of North African immigrants resulted in more votes for the Socialists and the Vlaams Blok. As a consequence, concerning the determinants of right-wing extremist election successes this ecological analysis finds that the Vlaams Blok's chances were significantly higher in areas with a high share of elderly inhabitants and immigrants as well as in inner cities.

According to an ecological analysis of the Hamburg state election of 1993, socio-economic problems in a district significantly increased the likelihood of good results for right-wing extremist parties as well as of abstentions. ${ }^{23}$ High local unemployment and social deprivation seemed to lead to a climate of insecurity, prejudice and political protest against established parties. An aggregate analysis of the Hamburg state election of $2001^{24}$ has shown that the 
success of the right-wing populist Schill Party in that election was significantly correlated to wealth (negatively) and living conditions (positively) in a city district. Other contextual variables like crime levels and population growth in the area remained insignificant.

An analysis of the determinants of right-wing extremist parties' shares of the votes in the municipal elections in Amsterdam in $1994^{25}$ has revealed a positive correlation of right-wing votes and the share of married couples as well as of ethnic minorities in the neighbourhood population. While overall immigration had a significant effect, the relative impact of Islamic immigrants (from Turkey or Morocco) was higher than the one of black immigrants (from Surinam or the Dutch Antilles). According to the authors of the study, this implies a clear differentiation of natives' threat perceptions of immigration along the lines of cultural and ethnic attributes of immigrants.

Concerning the determinants of the election successes of the extreme right Republikaner party in Germany in the 1990s, Lubbers and Scheepers have somewhat surprisingly found a significant negative effect of unemployment on the district level. ${ }^{26}$ Finally, our county-level analysis of right-wing extremist results in European elections in Germany in the $1990 \mathrm{~s}^{27}$ has chosen an ecological study design similar to ours presented here. Based on the empirical findings on significant context variables promoting extremist and populist voting behaviour, we conclude that democratic policies opposing right-wing parties should concentrate on differentiated concepts against unemployment, on social work with youngsters, and on maintaining substantial transfers within the framework of the welfare state.

\section{Right-wing extremist and populist parties in Hamburg}

A detailed overview of right-wing extremist and populist parties in Germany is given by Falter and Klein, Falter and Schumann, and Pappi. ${ }^{28}$ In our case, the city state of Hamburg, four parties are relevant: the National Democrats (NPD), Die Republikaner (REP), the German People's Union (DVU), and the party “Offensive of the Rule of Law” (PRO / "Schill Party”). Their performance in Hamburg elections since 1986 is given in Table 1.

The party "The Republicans" was founded in 1983. It has been trying to give a conservative impression but its actual ideological location is clearly extremist. The Republicans' programme and propaganda is nationalist and anti-European. Xenophibia and racist antiimmigration positions are partly supported by latent anti-semitism. Moreover, the democratic institutions of the Federal Republic of Germany are interpreted as results of Allied reeducation and enforcement contradicting the Germans' national pride. As a consequence, the liberal values of the post-1945 German constitution are seen as illegitimate. The Republicans are anti-American, they have a revisionist perception of national socialism, and tend to play down the crimes committed by Germans between 1933 and 1945, especially during World War II. The Republicans' high time in elections was the late 1980s and early 1990s. They reached 7.1 percent of the votes in the European elections of 1989, and 7.5, 4.9 and 10.9 in the state-level elections in Berlin in 1989, in Bavaria in 1990 and in Baden-Wuerttemberg in 1992, respectively. Since the mid-1990s the party has declined to about 1 to 3 percent of the votes in Germany, except for Baden-Wuerttemberg where it got more than 9 percent in the state elections in 1996 and in municipal elections in 1999. In Hamburg, the Republicans' best result was 4.8 percent in the state elections of 1993 . The current status of the party is characterized by internal quarrels and a persistent loss of members. 
One reason for the decline of the Republicans is the rise of strong populist competition by the "Deutsche Volksunion“ (German People’s Union, DVU) in the second half of the 1990s. The party was founded in 1987 as a platform for all nationalist groups. Its main aspects are xenophobia, anti-semitism, denial of German atrocities in World War II, anti-democratic authoritarianism and aggressive propaganda trying to win votes of young and socially marginalized people. The party had some success on the state level during the 1990s, e.g. in Schleswig-Holstein (1992: 6.3 percent; 1996: 4.3 percent), Saxony-Anhalt (1998: 12.9 percent), and Brandenburg (1999: 5.3 percent). Since then, however, the DVU's share of the votes has been declining (except for 2004 in Brandenburg (6.1 percent) and in the special case of Bremerhaven), and the party has not been able to get over the hurdle of 5 percent which the German election system demands for receiving seats in parliaments. In Hamburg, the DVU reached a maximum of 2.8 and 4.9 percent in the state elections of 1993 and 1999, respectively.

The traditional pool of neo-Nazi extremists is the National Democratic Party (NPD) founded in 1964. In 1966, during the so-called "second wave" of post-1945 right-wing election successes in Germany, the party gained 7.4 percent of the votes in Bavaria and 7.9 percent in Hesse. In 1967 the NPD achieved representation in several other state legislatures (RhinelandPalatinate: 6.9, Schleswig-Holstein: 5.8, Lower Saxony: 7.0, Bremen: 8.8 percent). After its greatest success in Baden-Wuerttemberg in 1968 (9.8 percent), the party failed in the Federal elections of 1969 (4.3 percent) and quickly lost support. Since the late 1990s, however, the NPD has been able to consolidate by cooperating with Skinheads and outspoken neo-Nazis. The party's programmatic aim is a "German" or "nationalist socialism" as opposed to the liberal-capitalist and democratic political system. The principle of "ethnic primacy" contains racist anti-immigrant positions, anti-semitism and an anti-pluralistic, totatitarian rule of elites modelled according to national socialism. Although the consolidation of the party has not resulted in election successes on the Federal or state level in the 1990s, NPD's potential has been demonstrated by up to 11.8 percent of the votes in municipal elections in Saxony in 1999 and in recent state-level elections in Saxony (2004: 9.2 percent) and MecklenburgVorpommern (2006: 7.3 percent). As a consequence, there has been an attempt to forbid the party, initiated by the federal government. This attempt, however, failed in 2003 because the German Constitutional Court (which has to decide about the dissolution of political parties) was confronted with illicit and unreliable evidence found by federal and state under-cover agents. In Hamburg, the NPD reached a maximum of 1.0 percent of the votes in the federal election of 2005.

While the three parties mentioned so far are clearly right-wing extremist and more or less neoNazi organisations, the fourth party we look at in our analysis is a clearly populist movement with law and order and anti-immigration positions. The party "Offensive of the Rule of Law" (PRO) was founded by a former judge, Ronald Schill, in $2000 .^{29}$ Schill had already become well known in the city as "Judge Merciless" due to his tough verdicts. The party programme emphasizes law and order, "abuse" of political asylum by immigrants and the need for (basically unwanted) immigrants to "assimilate". ${ }^{31}$ Some months after its foundation, the "Schill Party" gained 19.4 percent in the Hamburg state elections in 2001 and formed a coalition government with the Christian Democrats (CDU) and the Liberals. Schill became Senator (Minister) of the Interior. The party remained a local Hamburg phenomenon. After a number of scandals, including Schill's personal contacts to alleged criminals and his preference for nepotism and partying instead of leading his department, the coalition fell apart in late 2003: Schill had tried to blackmail the city's Lord Mayor (Prime Minister) by threatening to publish information about the former's alleged homosexuality. As a result, 
Schill was excluded from his party and re-founded a new one, the "PRO-DM/Schill" (Pro Deutsche Mitte/Pro German Centre) Party, together with a populist opponent of European Monetary Union heading a minor party ("PRO DM"). Neither PRO-DM nor PRO (Offensive D), now without its well-known head, were able to gain seats in the state elections of early 2004. They reached 3.1 and 0.4 percent of the votes, while the Christian Democrats gained 47.2 percent.

\section{Design of the empirical study}

\section{Dataset}

The empirical analysis we present in this paper is based on information on the district level of the German city state (Land) of Hamburg. Hamburg has about 1.7 millon inhabitants and 98 administrative districts. We have assembled data on the socio-economic conditions in the districts from official statistics since the mid-1980s. With this data, we have performed an ecological analysis of the county, state, federal and European elections since 1986. The data was provided by the Hamburg state and German federal statistical offices (http://www.statistik-bund.de/wahlen). ${ }^{32}$

Apart from taking part in the elections to the German Federal and European Parliaments, Hamburg citizens may elect their State Parliament (Bürgerschaft) with 121 seats, and seven county councils (Bezirksversammlungen) which are corporations for self-administration without legislative power and 41 seats each. Our endogenous variable is right-wing extremist and populist parties' election results as an indicator for anti-foreigner attitudes of natives, as compared to the established parties' (Social Democrats and Christian Democrats) results. Comparing the determinants of extremist and populist votes to the other parties' should give us an indication whether the conditions in which they are successful are similar. As a consequence we may conclude whether the radicals' claim to work for the "real" interests of the citizens and to follow truly important aims like law and order is true, as least as far as their voters' perception is concerned.

We also compare the contextual determinants of right-wing votes to those of their left-wing counterpart, the Party of Democratic Socialism (PDS), and a local center-right protest party, the STATT Party. The PDS is a successor of the ruling socialist party in the former GDR, which has been active in Hamburg since German unification. Apart from a leftist economic ideology the party's programme has been deliberately vague, emphasizing an ambivalent notion of "social justice". ${ }^{33}$ Concerning its potential to attract anti-establishment protest voters, the PDS might well be an alternative to right-wing populist parties. After all, rightwing parties are generally handicapped in the political process by the specter of Germany's Nazi past and organizational difficulties. ${ }^{34}$ The STATT Partei was founded after a ruling by Hamburg's Constitional Court in 1993 declared the 1991 state elections null and void due to serious violations of candidate selection rules in the CDU. Established as a centrist antiestablishment voters' association and based on a vague populist programme, the STATT Party received 5.6 percent of the vote in the Bürgerschaft election of $1993 .{ }^{35}$

Following previous considerations and findings cited above, in our empirical analysis, we focus on a set of exogenous contextual variables covering aspects that may increase the attractiveness of right-wing extremist and populist parties: immigration, unemployment, low education and skills, crime, and generally bad living conditions. We try to differentiate 
between level effects of e.g. immigration and dynamic effects resulting e.g. from an abrupt increase of foreign population in an area. After all, it seems obvious that a high influx of foreigners in a short period of time may cause more fears of being "overcrowded", and thus more xenophobia than a relatively constant, high stock of immigrants which one is already used to. The same holds for the unemployment or crime situation, or, for that matter, housing conditions. Massive increases in unemployment in the short run, for example, may give a more serious and urgent impression of a deteriorating economic situation than a high level of persistent unemployment.

We also differentiate the age structure of the indigenous population, unemployment and crime. Given previous results in the literature, we expect more elderly people to vote for right-wingers than youngsters. Youth unemployment may be a more serious political problem than unemployment of elderly workers, since for the young, it endangers their fundamental chances in life while for older workers, aged 55+, it might just be an inconvenient step towards retirement, especially if there are still early retirement schemes subsidized by the government. Therefore, high levels and increases of youth unemployment should improve the populists' opportunities to be elected when promising more jobs for nationals by applying slogans like "Germans first" or "No more subsidizing of idle asylum seekers" in labour market policy or in public finance. Similarly, we expect violent crimes to have a more frightening effect than mere thefts, thus providing higher incentives to vote for "law and order”.

The exogenous variables in our data set include information on:

- the stock and development of foreign population,

- the age structure of the population,

- the number and development of welfare recipients,

- the local unemployment and wage situation,

- employment (skills) and education of the inhabitants,

- general housing conditions as an additional proxy for social status,

- the local crime situation (thefts and violent crimes), and

- general information on infrastructure (private transport and education) as a measure of mobility/closedness and educational opportunities in the the area.

In order to improve the reader's orientation we have grouped the variables into seven categories. It has to be noted, however, that while these categories cover different dimensions of spatially defined living conditions they are not mutually exclusive and may well overlap from a theoretical point of view. All data have been assembled for the district level. Table 2 gives an overview of the variables in our data set.

\section{Statistical method}

The econometric approach we apply in this paper is based on an adaption of the simple linear regression for panel data with unobeserved heterogeneity and potential heteroskedasticity. We use a Feasible Generalized Least Squares Random Effects Panel Model (FGLS-REPM). ${ }^{36}$ Apart from taking account of the potential violation of the standard OLS assumption that the variance of the error term $e$ be constant, the model introduces an additional, randomly distributed error term $u$ which varies across the observations but is constant over time. This error term covers unobserved or unobservable heterogeneity i.e. individual socio-economic particularities of the districts in our data set. The regression equation of the model is: 


$$
y_{i t}=a_{0}+a_{1} x_{1 i t}+a_{2} x_{2 i t}+\ldots+u_{i}+e_{i t} \quad(i=1, \ldots, N ; t=1, \ldots, T)
$$

with $y_{i t}=$ percentage of votes for a party (party group) in Hamburg elections 1986-2005; $x=$ exogenous variables; $i=$ voting district; $t=$ time; $u_{i}=$ district specific error term; $e_{i t}=$ error term. We use additional yearly and election dummies variables in order to cover special conditions given by the level of an election (European, federal, state or local) and by time contingency. From a political science perspective, for example, one would expect that voting behaviour, just like voter turnout, might be different in "second-order" elections, such as European elections (perceived as less substantial for policies) than in "first order" elections such as Bundestag elections. The county elections of 2001 serve as a reference group.

We have estimated a number of models for the Hamburg elections from 1986 to 2005. They cover the ecological determinants of results of the three extremist parties (NPD, "Republicans" and DVU) combined and seperately, and of the right-wing populist "Schill Party" (PRO) and its splitted successors. In order to compare the right-wing parties' performance to the established parties' and other protest parties', we have added estimations for the CDU and SPD as well as for the PDS and STATT Party. For each party we have estimated three alternative specifications with varying differentiations of the socio-economic and crime situations in the city districts.

\section{Central Findings}

Our estimation results give a complex and differentiated picture of the ecological determinants of party election performance in Hamburg from 1986 to 2005. The overall goodness-of-fit of our models (which obviously varies according to the number of observations available) is very convincing. Concerning the dummies for elections and election years we find that about two thirds of them are highly significant but do not reveal a consistent pattern according to the perceived importance of elections as we expected.

We summarize our results in four steps. First, for the right-wing extremist parties (Tables 3 and 4) we receive interestingly differentiated findings:

(1) Immigration: While right-wing extremist parties did significantly better in districts with a high share of immigrant population this effect cannot be ascribed to a single party. On the contrary, the Republicans reveived more votes in areas with a relatively small foreign population. What is striking about the role of immigrants is the clearly significant positive impact of increasing shares of foreigners in a district. Except for the NPD, the dynamics of immigration promoted election chances of right-wing extremist parties.

(2) Demography: Concerning the age structure of the native population, right-wing extremist parties performed better where there was a high share of youngsters and where the number of elderly people had been increasing. The former effect, however, cannot be verified for a single party, while the latter is driven by the results of the DVU. Moreover, it is remarkable that the NPD was significantly more successful in areas with a high stock of elderly people but less attractive in districts with a high increase of elderly. This hints at a NPD speciality since it implies the need of differentiating between "younger” and "older” elderly people.

(3) Education and occupation: While a relatively high share of academically educated population did not affect significantly overall right-wing extremist election results, the DVU 
and the NPD were significantly more attractive in districts with a higher share of less educated inhabitants. Lower shares of self-employed and higher shares of blue-collar workers in an area increased right-wing extremists' chances to be elected, which is driven by the performance of the Republicans.

(4) Housing conditions: Right-wing extremist parties had better election chances in districts with a high share of community flats. Housing conditions, however, did not have a coherent effect on all parties' results. While the general finding is supported for the Republicans only, the DVU seems to have been more successful in areas with high but decreasing per capita housing space and low numbers of inhabitants per household. This might hint at the party's high attractiveness in areas with a high and increasing share of single households (in recently constructed smaller flats). On the other hand, the NPD gained more votes in districts with bigger households.

(5) Welfare: Relatively high and increasing welfare reception in a city district raised the general likelihood of votes for right-wingers. Accordingly, an increase in the share of (male) employees subject to social insurance contributions had a negative impact. Nevertheless, the level effect of welfare reception was positive for the DVU and negative for the Republicans, and the dynamic effect was negative for the DVU and positive for the Republicans. None of this was significant in the case of the NPD.

(6) Unemployment: High unemployment levels increased the attractiveness of the NPD, while decreasing it for the other right-wing extremist parties. Fast rising unemployment, however, had a positive effect on all right-wing extremist parties' share of the vote. Except for the contrary effect for the NPD, it was especially youth unemployment which fostered right-wing extremist election results, although the dynamic effect was negative for the DVU and the Republicans. Rising unemployment among the elderly was negative for the DVU and positive for the Republicans.

(7) Crime: The crime level in the districts of Hamburg had a significantly positive effect only for the Republicans. A surge in criminal acts, especially thefts, had even a negative overall impact which was driven by the Republicans' and the NPD's results. For the DVU, the effect was reverse.

(8) Infrastructure: Concerning a district's general infrastructure high levels of private mobility and a small number of elementary and primary education institutions increased the likelihood of right-wing extremists' election successes. These effects, however, can be hardly ascribed to single parties.

Right-wing populist parties also display heterogenous estimation results (Table 5):

(1) Immigration and demography: The Schill Party, Pro DM/Schill and Offensive D performed significantly better in districts experiencing a strong influx of immigrants. Offensive D also reached more votes in areas with a high share of elderly people.

(2) Education and occupation: While the Schill Party displayed a significantly higher attractiveness in districts with a relatively low-educated population, Pro/DM was less successful in the presence of a high share of self-employed. Offensive D gained significantly more votes in areas with a high share of workers in the population. 
(3) Housing conditions: Housing conditions were not significant for the performance of the Schill Party. Pro DM was less attractive in districts with a high share of community flats and increasing housing space per capita. Pro DM/Schill and Offensive D, on the other hand, were successful in areas with improving habitation conditions although Pro DM/Schill performed below average where housing space p.c. was high.

(4) Welfare: Concerning the effect of welfare reception and social insurance status, the Schill Party and Pro DM/Schill experienced lower shares of the vote in districts where welfare reception increased. The Schill Party also lost where social insurance relevant jobs were relatively more frequent. Offensive $\mathrm{D}$ had better chances to succeed in districts with a rising share of welfare recipients.

(5) Labour market and unemployment: While a high level of unemployment was negative for the Schill Party, its (and Pro DM/Schill's) votes increased significantly where unemployment increased strongly. This effect was driven by unemployment and unemployment dynamics of the elderly while youth unemployment displayed the reverse impact. Pro DM displayed a negative unemployment level effect for elderly unemployed and Offensive D a positive one. Both gained significantly in districst with high unemployment dynamics for elderly people. One may also note that Offensive D attracted significant more votes in areas with a relatively high share of the workforce occupied in low-wage jobs.

(6) Crime: The Schill Party's opportunities to be elected increased significantly with a high level of thefts while crime in general and violent crimes remained insignificant. Security issues played no significant role in the performance of Pro DM/Schill and Offensive D. Pro $\mathrm{DM}$, however, performed significantly better with high levels of thefts but worse with general increases of crime including acts of violence.

(7) Infrastructure: Pro DM/Schill performed significantly better in districts with high private mobility opportunities while Pro DM's results were negatively affected by private transport infrastructure and positively by a high supply of secondary education institutions.

It is interesting to see where the right-wing extremist and populist parties' ecological determinants of success diverge from those of the established big parties CDU and SPD (Table 6):

(1) Immigration and demography: While the CDU seemed more attractive in districts with a high share of foreigners and less in those with a high proportion of youngsters, SPD votes were significantly higher in areas with relatively few immigrants. Both parties received more votes in districts with many elderly inhabitants.

(2) Occupation and education: Higher shares of academics and blue-collar workers decreasd the Christian Democrats election chances, while districts with relatively many self-employed were favorable for them. The SPD won significantly in blue-collar workers' areas and lost in districts with high share of self-employed.

(3) Housing conditions, welfare and unemployment: The CDU performed significantly better in areas with relatively good housing conditions (space p.c.), bigger households and high shares of males employed in social insurance relevant jobs. Welfare reception and unemployment remained insignificant, while the Christian Democrats were more attractive in districts with relatively high proportion of inhabitants in well-paid jobs. Turnout for the SPD 
was promoted significantly in areas with many community flats, a high share of unemployed and a fast increase in welfare recipients. Nevertheless, the Social Democrats performed worse in districts with a positive development of housing space, high levels of welfare reception and strong unemployment dynamics (except for elderly unemployed).

(4) Crime: The CDU's election performance was negatively affected by high crime levels, especially violent criminal acts whereas the SPD gained votes in situations with increasing numbers of criminal acts, especially thefts.

(5) Infrastructure: CDU shares of the vote were negatively correlated to elementary and secondary education opportunities in an area, while SPD votes increased in contexts of better secondary school facilities and decreased with an improved supply in primary schooling.

Finally, our estimations for the alternatives for protest voters, the PDS and the STATT Party may be summarized as follows (Table 7):

(1) Immigration and demography: PDS and STATT Party received significantly less votes in areas with high levels of foreign population and a great influx of immigrants, respectively. Moreover, the Socialists were less popular in districts with a high share of elderly inhabitants.

(2) Occupation and education: While the education variables remained insignificant in the case of the PDS STATT was less attractive in areas with a high share of university graduates, self-employed and blue-collar workers, indicating that the party was especially successful in petty bourgeois districts.

(3) Housing conditions and welfare: Both parties did significantly worse than average in districts with a high share of community flats and high welfare reception dynamics. Nevertheless PDS votes increased with the level of welfare reception.

(4) Unemployment and labour market: The Socialists were significantly more attractive in areas with high and increasing unemployment. While this applied especially to elderly unemployed, the level of youth unemployed dampened this result. STATT Party received less votes in districts with increasing unemployment among the elderly and performed better in "high wage" populations.

(5) Crime: While PDS results were positively correlated to the crime level (driven by violent crimes and dampened by thefts), the STATT Party lost when criminal acts, especially violent crimes increased.

(6) Infrastructure: The only significant effect of the general infrastructure variables was a negative impact of good primary education facilities for the STATT Party.

\section{Conclusions}

Given that our estimation results are comlex and heterogenous, we provide a qualitative heuristic summary of the main effects for the most important parties in Table 8. One has to note that ambivalent outcomes, especially for welfare and unemployment effects, depend mainly on contradicting impacts of level and dynamic aspects. As a general result of our analysis we agree to the literature that it is necessary to differentiate between right-wing 
extremist and right-wing populist parties ${ }^{37}$. Morevoer, our findings indicate that this also holds for the need to differentiate among extremist and populist parties as far as the effects of our spatial socio-economic variables are concerned. What strikes us most is the extraordinary position of the NPD among the extremist parties: To a very large degree we have not found significant connections between the National Democrats' election results and their contextual framework. We take this as general support for the hypothesis that the NPD's attractiveness among parts of the electorate is mainly driven by hardened ideological (neo-Nazi) attitudes instead of specific social or economic problems.

Nevertheless, there are similarities in the context making right-wing extremist parties attractive to voters. The starting hypothesis of this paper was the theoretically and empirically founded idea that right-wing election successes are mainly driven by immigration, social status/deprivation (occupation, education, unemployment), and fear of crime (i.e. a "law and order" orientation). Summarizing our findings we may conclude that, by and large, this is confirmed by our results as far as immigration and social status is concerned. Except for the NPD (!) right-wing extremist parties are significantly more successful in areas with high and/or increasing shares of foreign population, with a high proportion of blue-collar workers in the population and relatively bad housing conditions. The role of crime, however, is not straightforward. The "law and order" aspect of right-wing extremism cannot be confirmed from our ecological results, especially if one takes into account that there seems to be a general connection between the share of elderly people in an area and the attractiveness of right-wing extremist parties.

The effects of unemployment are also mixed: Again except for the NPD, high unemployment levels tend to decrease right-wing extremists' election chances. This finding is in accordance to the results of other ecological studies which have identified different empirical effects ranging from a positive impact of unemployment when immigration levels are high to a negative effect similar to ours. ${ }^{38}$ Our result is also in line with the study by Lubbers and Scheepers which has triggered a methodological debate in empirical political science. ${ }^{39}$ Our operationalization of the unemployment variables might give a hint to solve the problem of how to explain this counterintuitive result. For the dynamic effect of rising unemployment is significantly positive for all right-wing extremist parties and confirms the theoretical hypothesis that social deprivation promotes their attractiveness among voters. This being said we remind the reader that this macro-level finding gives no explanation of the micro-level mechanism of indivdual decision-making. Similar to the NSDAP case mentioned above, it may be recently laid-off as well as still employed workers (being afraid of losing their job too) or enraged bystanders who vote for right-wing extremist parties in the face of rising unemployment. What is important for our research question is the significantly positive correlation between right-wing extremism and unemployment dynamics.

Given the ecological determinants of right-wing extremist election successes, and keeping in mind the special characteristics of the NPD, we are able to identify three broad fields of policies against right-wing extremism: First, democratic policies have to aim at avoiding abrupt increases in unemployment, creating a general atmosphere of job insecurity and endangered opportunities to make a living. Second, improvements in housing conditions also seem to reduce the attractiveness of right-wing political extremism. Both points emphasize the importance of a sustainable structural policy on the local and regional levels. Third, the most important instrument is investment in education and professional qualification, i.e. education policy is a first priority. A better educated and well-skilled electorate seems to be the best guarantee against political xenophobia and chauvinism. 
The common denominator of right-wing populists' election successes from an ecological perspective is significance of immigrant influx as well as unemployment and welfare reception dynamics. The issues of immigration and unemployment are of similar importance for populists as for extremists. Nevertheless, demographic, educational and housing conditions seem to be less crucial. Moreover, similarities between the ecological determinants of right-wing populist election results and those of the established and alternative protest parties are clearly limited. This implies that socialist and centrist (anti-establishment) protest parties are no real alternatives to vote for in similar local conditions, especially if those protest parties' structural prerequisites of success are similar to the big parties, like in the case of the STATT Party and the CDU.

The most interesting result for the right-wing populists around Roland Schill is the effect of crime and public order problems which have played the foremost role in their programmes and campaigns. Election analyses based on survey data have claimed that at least PRO/Schill Partei was perceived as the most competent champion in the fight against crime and that crime was the foremost problem in Hamburg. ${ }^{40}$ This image, however, is only partly mirrored in our ecological results: Neither the level nor the development of overall crime or acts of violence had a significant effect of the share of votes for the right-wing populists. Only crimes against property displayed a significant impact according to our expectations. This finding may hint at another aspect of voting behaviour which is not covered by our ecological dataset: A number of empirical studies have found that the actual number of immigrants is less important than media coverage of immigration. Similarly, perceived criminal threat may also depend on impressions shaped by television, the press and other sources of information. ${ }^{41}$ As a consequence, perception and media coverage seem to be as important for right-wing election successes as actual real world problems modelled by ecological election analysis. 
Table 1: Election results in Hamburg, 1986-2005 (\% share of vote)

\begin{tabular}{|c|c|c|c|c|c|c|c|c|c|c|c|}
\hline Election & SPD & $\mathrm{CDU}$ & NPD & REP & DVU & $\begin{array}{c}\text { STATT } \\
\text { Partei }\end{array}$ & Pro DM & $\begin{array}{l}\text { PRO / } \\
\text { Schill }\end{array}$ & $\begin{array}{c}\text { Pro DM } \\
\text { / Schill }\end{array}$ & $\begin{array}{c}\text { PRO / } \\
\text { Offensive D }\end{array}$ & $\begin{array}{c}\text { PDS / } \\
\text { Die Linke }\end{array}$ \\
\hline State 1986 & 441.7 & 41.9 & "--- & ב--- & "--- & "--- & " --- & "--- & "--- & " --- & (2-- \\
\hline County 1986 & 39.9 & 41.3 & --- & --- & --- & --- & --- & --- & --- & --- & --- \\
\hline Federal 1987 & 41.2 & 37.4 & 0.4 & --- & --- & --- & --- & --- & --- & --- & --- \\
\hline State 1987 & 45.0 & 40.5 & -- & --- & --- & --- & --- & --- & --- & --- & --- \\
\hline County 1987 & 43.0 & 39.8 & --- & --- & --- & --- & --- & --- & --- & --- & --- \\
\hline EU 1989 & 41.9 & 31.5 & --- & 6.0 & 1.5 & --- & --- & --- & --- & --- & --- \\
\hline Federal 1990 & 41.0 & 36.6 & 0.3 & 1.7 & --- & --- & --- & --- & --- & --- & $1.1^{*}$ \\
\hline State 1991 & 48.0 & 35.1 & --- & 1.2 & --- & --- & --- & --- & --- & --- & $0.5^{*}$ \\
\hline County 1991 & 45.6 & 35.0 & --- & 1.1 & --- & --- & --- & --- & --- & --- & $0.3^{*}$ \\
\hline State 1993 & 40.4 & 25.1 & --- & 4.8 & 2.8 & 5.6 & --- & --- & --- & --- & $0.5^{* *}$ \\
\hline County 1993 & 38.3 & 25.6 & --- & 4.5 & 2.9 & 5.9 & --- & --- & --- & --- & --- \\
\hline EU 1994 & 34.6 & 32.1 & 0.2 & 3.1 & -.0 & 1.8 & --- & --- & --- & --- & 1.4 \\
\hline Federal 1994 & 39.7 & 34.9 & --- & 1.7 & --- & --- & --- & --- & --- & --- & 2.2 \\
\hline State 1997 & 36.2 & 30.7 & 0.1 & 1.8 & 5.0 & 3.8 & --- & --- & --- & --- & $0.7^{*}$ \\
\hline County 1997 & 34.7 & 30.8 & 0.2 & 2.1 & 5.3 & 4.0 & --- & --- & --- & --- & $0.3^{*}$ \\
\hline Federal 1998 & 45.7 & 30.0 & 0.1 & 0.6 & 2.1 & --- & 0.3 & --- & --- & --- & 2.3 \\
\hline EU 1999 & 37.2 & 40.2 & 0.3 & 1.0 & --- & --- & --- & --- & --- & --- & 3.3 \\
\hline State 2001 & 36.5 & 26.2 & --- & 0.1 & 0.7 & 0.4 & 0.2 & 19.4 & --- & --- & $0.4^{* * *}$ \\
\hline County 2001 & 34.3 & 27.0 & 0.0 & 0.1 & 0.8 & 0.6 & --- & 18.5 & --- & --- & $0.5^{* * *}$ \\
\hline Federal 2002 & 42.0 & 28.1 & 0.2 & 0.1 & --- & --- & --- & 4.2 & --- & --- & 2.1 \\
\hline State 2004 & 30.5 & 47.2 & 0.3 & -- & --- & --- & --- & --- & 3.1 & 0.4 & --- \\
\hline County 2004 & 30.0 & 44.7 & 0.5 & --- & --- & --- & --- & --- & 2.0 & 0.7 & $0.4^{* * * *}$ \\
\hline EU 2004 & 25.3 & 36.7 & 0.4 & 0.4 & --- & --- & --- & --- & -- & -- & 2.8 \\
\hline Federal 2005 & 38.7 & 28.9 & 1.0 & --- & -- & --- & --- & --- & --- & --- & 6.3 \\
\hline
\end{tabular}

Note: $\quad$ EU = Election of the European Parliament; Federal = Elections of the Bundestag; State = Election of the Bürgerschaft $($ State Parliament); County = Election of Bezirksversammlungen (municipal districts) ; * PDS/Linke Liste; ** Linke Alternative; ***PDS Hamburg; **** PDS Altona / PDS Wandsbek 
Table 2: Variables in the data set

\begin{tabular}{|c|c|c|c|c|c|}
\hline Variable & Definition & Mean & Std.Dev. & Min & Max \\
\hline \multicolumn{6}{|l|}{ Party (Share of votes of ...) } \\
\hline SPD & Share of votes of the Social Democratic Party of Germany (SPD) & 0.382 & 0.095 & 0.120 & 0.637 \\
\hline CDU & Share of votes of the Christian Democratic Party (CDU) & 0.353 & 0.107 & 0.096 & 0.698 \\
\hline NPD & Share of votes of the National Democratic Party (NPD) & 0.003 & 0.004 & 0.000 & 0.025 \\
\hline REP & Share of votes of the "Republicans" (REP) & 0.019 & 0.021 & 0.000 & 0.136 \\
\hline DVU & Share of votes of the German People’s Union (DVU) & 0.028 & 0.024 & 0.000 & 0.148 \\
\hline RECHTE & $\begin{array}{l}\text { Total share of votes of the National Democratic Party, "Republicans" and German } \\
\text { People's Union (NPD, REP, DVU = RECHTE) }\end{array}$ & 0.029 & 0.033 & 0.000 & 0.205 \\
\hline STATT & Share of votes of the Party "STATT Partei - Die Unabhängigen" & 0.032 & 0.024 & 0.000 & 0.110 \\
\hline Pro DM & Share of votes of the Party "Pro DM" & 0.003 & 0.002 & 0.000 & 0.010 \\
\hline Schill & Share of votes of the Party "Partei Rechtsstaatlicher Offensive (Schill-Partei)" & 0.141 & 0.084 & 0.012 & 0.359 \\
\hline Pro DM / Schill (Schill 2) & Share of votes of the Party "Pro DM/Schill” & 0.026 & 0.020 & 0.000 & 0.088 \\
\hline PRO / Offensive D & Share of votes of the Party "Partei Rechtsstaatlicher Offensive (Offensive D)" & 0.006 & 0.006 & 0.000 & 0.034 \\
\hline PDS / Die Linke & Share of votes of the Party "PDS / Die Linke" & 0.016 & 0.020 & 0.000 & 0.170 \\
\hline Election (year) & $\begin{array}{l}\text { Dummy variable for election on the state level (Bürgerschaft = State parliament), } \\
\text { county level (Bezirksversammlung = County council), federal level (Bundestag = } \\
\text { Federal parliament) and of the European Parliament in (year) }\end{array}$ & --- & --- & --- & --- \\
\hline \multicolumn{6}{|c|}{ 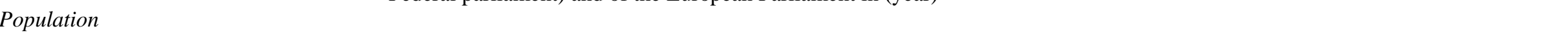 } \\
\hline Foreigners & Share of foreigners in population in an election year & 0.143 & 0.119 & 0.005 & 0.783 \\
\hline Change in foreigners & Change in the share of foreigners in population during the previous term & 0.007 & 0.026 & -0.128 & 0.207 \\
\hline Young Germans & Share of young Germans (aged 18-34) in population & 0.227 & 0.057 & 0.139 & 0.466 \\
\hline Elderly Germans & Share of elderly Germans (aged 65+) in population & 0.169 & 0.044 & 0.041 & 0.294 \\
\hline Change in elderly Germans & $\begin{array}{l}\text { Change in the share of elderly Germans (aged 65+) in population during the } \\
\text { previous term }\end{array}$ & 0.001 & 0.013 & -0.058 & 0.052 \\
\hline \multicolumn{6}{|l|}{ Education / Occupation } \\
\hline High-skilled & $\begin{array}{l}\text { Share of persons with completed tertiary education (University or University of } \\
\text { Applied Sciences / Fachhochschule degree) in the employed labour force }\end{array}$ & 0.215 & 0.110 & 0.064 & 0.509 \\
\hline Self-employed & Share of self-employed & 0.119 & 0.070 & 0.023 & 0.304 \\
\hline Blue-collar workers & Share of blue collar workers in the employed labour force & 0.309 & 0.126 & 0.073 & 0.646 \\
\hline \multicolumn{6}{|c|}{ - } \\
\hline Council flats & Share of council flats in total number of flats in an election year & 0.155 & 0.154 & 0.000 & 0.724 \\
\hline Housing space & Average housing space per person $\left(\mathrm{m}^{2}\right)$ & 0.353 & 0.062 & 0.113 & 0.649 \\
\hline Change in housing space & Change in housing space per person during the previous term & 0.006 & 0.020 & -0.148 & 0.293 \\
\hline Persons per houshold & Number of persons living in a household in an election year & 2.006 & 0.303 & 1.530 & 2.790 \\
\hline
\end{tabular}


Welfare reception

Change in welfare reception

Employees

Male employees

Female employees

Labour market

Unemployment

Change in unemployment

Youth unemployment

Change in youth unemployment

Unemployment, age 55-65

Change in unemployment, age 55-65

Wage

Crime

Criminal acts

Change in Criminal acts

Thefts

Change in thefts

\section{Violent crimes}

Change in violent crimes

\section{Infastructure}

Cars

Kindergarten

Primary school

Secondary school
Share of welfare recipients in inhabitants in an election year

Change in share of welfare recipients during the previous term

Share of employees subject to social insurance contributions (aged 15-65) in population

Share of male employees subject to social insurance contributions (aged 15-65) in male population

Share of female employees subject to social insurance contributions (aged 15-65) in female population

Unemployment rate in an election year

Change in the unemployment rate during the previous term

Unemployment rate of persons aged 15-25 in an election year

Change in the unemployment rate of persons aged 15-25 during the previous term

Unemployment rate of persons aged 55-65 in an election year

Change in the unemployment rate of persons aged 55-65 during the previous term Average yearly income (in DM)

Number of Criminal acts registered by the police per 1,000 inhabitants in

Hamburg in an election year

Change in number of Criminal acts registered by the police per 1,000 inhabitants during the previous term

Number of thefts registered by the police per 1,000 inhabitants in an election year

Change in number of registered thefts per 1,000 inhabitants during the previous

term

Number of violent crimes registered by the police per 1,000 inhabitants in an

election year

Change in number of registered violent crimes per 1,000 inhabitants during the previous term

Number of private passenger cars per 1,000 inhabitants in an election year

Share of places in kindergarten for children between three and six years

Number of primary schools / population

Number of secondary schools / population

$\begin{array}{rrrr}0.057 & 0.040 & 0.000 & 0.270 \\ 0.004 & 0.016 & -0.139 & 0.102 \\ 0.451 & 0.057 & 0.155 & 0.638 \\ & & & \\ 0.476 & 0.063 & 0.149 & 0.634 \\ & & & \\ 0.426 & 0.063 & 0.135 & 0.643 \\ & & & \\ 0.063 & 0.029 & 0.009 & 0.203 \\ -0.000 & 0.014 & -0.101 & 0.102 \\ 0.046 & 0.024 & 0.000 & 0.181 \\ -0.003 & 0.014 & -0.074 & 0.068 \\ 0.061 & 0.028 & 0.000 & 0.197 \\ -0.003 & 0.017 & -0.112 & 0.116 \\ 63039 & 24188 & 29333 & 316250\end{array}$

$\begin{array}{llll}224.515 & 666.200 & 20 & 12953\end{array}$

$\begin{array}{llll}0.013 & 0.327 & -0.795 & 4.271\end{array}$

$134.475 \quad 389.202 \quad 8 \quad 4845$

$\begin{array}{llll}-0.039 & 0.366 & -0.807 & 6.444\end{array}$

$\begin{array}{llll}5.403 & 12.801 & 0 & 158\end{array}$

$\begin{array}{llll}0.209 & 0.673 & -1.000 & 10.000\end{array}$

$\begin{array}{llll}385.836 & 88.024 & 114 & 792\end{array}$

$\begin{array}{llrr}94.434 & 23.078 & 36.700 & 159.600\end{array}$

$\begin{array}{llll}0.002 & 0.002 & 0.000 & 0.013\end{array}$

\begin{tabular}{llll}
0.001 & 0.002 & 0.000 & 0.012 \\
\hline
\end{tabular}


Table 3: Determinants of right wing extremist parties' election performance: NPD, REP and DVU combined

\begin{tabular}{|c|c|c|c|}
\hline Variable & Rechte & Rechte & Rechte \\
\hline \multicolumn{4}{|l|}{ Population } \\
\hline Foreigners & $\begin{array}{c}0,016 \\
(1,72)^{*}\end{array}$ & $\begin{array}{c}0,018 \\
(2,02)^{* *}\end{array}$ & $\begin{array}{c}0,016 \\
(1,79)^{*}\end{array}$ \\
\hline Change in foreigners & $\begin{array}{c}0,125 \\
(8,18)^{* * *}\end{array}$ & $\begin{array}{c}0,123 \\
(7,99)^{* * *}\end{array}$ & $\begin{array}{c}0,124 \\
(8,01)^{* * *}\end{array}$ \\
\hline Young Germans & $\begin{array}{c}0,050 \\
(2,76)^{* * *}\end{array}$ & $\begin{array}{c}0,046 \\
(2,40)^{* *}\end{array}$ & $\begin{array}{c}0,043 \\
(2,29)^{* *}\end{array}$ \\
\hline Elderly Germans & $\begin{array}{l}0,022 \\
(1,39)\end{array}$ & $\begin{array}{l}0,020 \\
(1,27)\end{array}$ & $\begin{array}{l}0,021 \\
(1,37)\end{array}$ \\
\hline Change in elderly & $\begin{array}{c}0,115 \\
(3,16)^{* * *}\end{array}$ & $\begin{array}{c}0,126 \\
(3,47)^{* * *}\end{array}$ & $\begin{array}{c}0,118 \\
(3,23)^{* * *}\end{array}$ \\
\hline \multicolumn{4}{|l|}{ Education/occupation } \\
\hline High-skilled & $\begin{array}{l}-0,020 \\
(-1,41)\end{array}$ & $\begin{array}{l}-0,021 \\
(-1,47)\end{array}$ & $\begin{array}{l}-0,019 \\
(-1,29)\end{array}$ \\
\hline Self-employed & $\begin{array}{c}-0,043 \\
(-3,32)^{* * *}\end{array}$ & $\begin{array}{c}-0,039 \\
(-3,05)^{* * *}\end{array}$ & $\begin{array}{c}-0,042 \\
(-3,27)^{* * *}\end{array}$ \\
\hline Blue-collar & $\begin{array}{c}0,047 \\
(3,63)^{* * *}\end{array}$ & $\begin{array}{c}0,048 \\
(3,57)^{* * *}\end{array}$ & $\begin{array}{c}0,050 \\
(3,73)^{* * *}\end{array}$ \\
\hline \multicolumn{4}{|l|}{ Housing } \\
\hline Council flats & $\begin{array}{c}0,014 \\
(3,75)^{* * *}\end{array}$ & $\begin{array}{c}0,015 \\
(3,98)^{* * *}\end{array}$ & $\begin{array}{c}0,015 \\
(3,84)^{* * *}\end{array}$ \\
\hline Housing space & $\begin{array}{l}0,022 \\
(1,37)\end{array}$ & $\begin{array}{l}0,020 \\
(1,26)\end{array}$ & $\begin{array}{l}0,022 \\
(1,41)\end{array}$ \\
\hline Change in housing space & $\begin{array}{l}0,013 \\
(0,66)\end{array}$ & $\begin{array}{l}0,014 \\
(0,70)\end{array}$ & $\begin{array}{l}0,012 \\
(0,57)\end{array}$ \\
\hline Persons per household & $\begin{array}{c}-0,005 \\
(-1,77)^{*}\end{array}$ & $\begin{array}{l}-0,004 \\
(-1,34)\end{array}$ & $\begin{array}{l}-0,004 \\
(-1,16)\end{array}$ \\
\hline \multicolumn{4}{|c|}{ General socio-economic environment } \\
\hline Welfare reception & $\begin{array}{c}0,072 \\
(3,03)^{* * *}\end{array}$ & $\begin{array}{c}0,069 \\
(2,89)^{* * *}\end{array}$ & $\begin{array}{c}0,070 \\
(2,93)^{* * *}\end{array}$ \\
\hline Change in welfare reception & $\begin{array}{c}0,075 \\
(2,74)^{* * *}\end{array}$ & $\begin{array}{c}0,072 \\
(2,65)^{* * *}\end{array}$ & $\begin{array}{c}0,076 \\
(2,77)^{* * *}\end{array}$ \\
\hline Employees & $\begin{array}{c}-0,053 \\
(-3,68)^{* * *}\end{array}$ & --- & --- \\
\hline Female employees & --- & $\begin{array}{l}-0,007 \\
(-0,44)\end{array}$ & $\begin{array}{l}-0,008 \\
(-0,49)\end{array}$ \\
\hline Male employees & --- & $\begin{array}{c}-0,040 \\
(-3,24)^{* * *}\end{array}$ & $\begin{array}{c}-0,039 \\
(-3,13)^{* * *}\end{array}$ \\
\hline \multicolumn{4}{|l|}{ Labour market } \\
\hline Unemployment & $\begin{array}{c}-0,272 \\
(-4,79)^{* * *}\end{array}$ & $\begin{array}{c}-0,282 \\
(-4,92)^{* * *}\end{array}$ & $\begin{array}{c}-0,277 \\
(-4,84)^{* * *}\end{array}$ \\
\hline Change in unemployment & $\begin{array}{c}0,275 \\
(4,61)^{* * *}\end{array}$ & $\begin{array}{c}0,282 \\
(4,70)^{* * *}\end{array}$ & $\begin{array}{c}0,279 \\
(4,65)^{* * *}\end{array}$ \\
\hline Youth unemployment & $\begin{array}{c}0,179 \\
(4,66)^{* * *}\end{array}$ & $\begin{array}{c}0,178 \\
(4,63)^{* * *}\end{array}$ & $\begin{array}{c}0,180 \\
(4,69)^{* * *}\end{array}$ \\
\hline Change in youth unemployment & $\begin{array}{l}-0,037 \\
(-1,03)\end{array}$ & $\begin{array}{l}-0,040 \\
(-1,09)\end{array}$ & $\begin{array}{l}-0,039 \\
(-1,07)\end{array}$ \\
\hline Unemployment, age 55-65 & $\begin{array}{l}0,006 \\
(0,19)\end{array}$ & $\begin{array}{l}0,015 \\
(0,46)\end{array}$ & $\begin{array}{l}0,007 \\
(0,20)\end{array}$ \\
\hline $\begin{array}{l}\text { Change in unemployment, age } \\
55-65\end{array}$ & $\begin{array}{l}-0,031 \\
(-0,94)\end{array}$ & $\begin{array}{l}-0,037 \\
(-1,11)\end{array}$ & $\begin{array}{l}-0,032 \\
(-0,97)\end{array}$ \\
\hline 然 & $\begin{array}{l}-0,000 \\
(-0,71)\end{array}$ & $\begin{array}{l}-0,000 \\
(-0,72)\end{array}$ & $\begin{array}{l}-0,000 \\
(-0,71)\end{array}$ \\
\hline
\end{tabular}




\begin{tabular}{|c|c|c|c|}
\hline \multicolumn{4}{|l|}{ Crime } \\
\hline Criminal acts & --- & $\begin{array}{l}0,000 \\
(0,70)\end{array}$ & --- \\
\hline Change in Criminal acts & --- & $\begin{array}{c}-0,002 \\
(-1,96)^{* *}\end{array}$ & --- \\
\hline Thefts & $\begin{array}{l}-0,000 \\
(-0,49)\end{array}$ & --- & $\begin{array}{l}-0,000 \\
(-0,49)\end{array}$ \\
\hline Change in thefts & $\begin{array}{l}-0,001 \\
(-0,89)\end{array}$ & --- & $\begin{array}{l}-0,001 \\
(-0,92)\end{array}$ \\
\hline Violent crimes & $\begin{array}{l}0,000 \\
(1,39)\end{array}$ & --- & $\begin{array}{l}0,000 \\
(1,42)\end{array}$ \\
\hline Change in violent crimes & $\begin{array}{l}-0,001 \\
(-1,61)\end{array}$ & --- & $\begin{array}{l}-0,001 \\
(-1,56)\end{array}$ \\
\hline \multicolumn{4}{|l|}{ Infrastructure } \\
\hline Cars & $\begin{array}{c}0,000 \\
(5,99)^{* * *}\end{array}$ & $\begin{array}{c}0,000 \\
(5,64)^{* * *}\end{array}$ & $\begin{array}{c}0,000 \\
(5,77)^{* * *}\end{array}$ \\
\hline Kindergarten & $\begin{array}{c}-0,000 \\
(-1,68)^{*}\end{array}$ & $\begin{array}{c}-0,000 \\
(-1,73)^{*}\end{array}$ & $\begin{array}{c}-0,000 \\
(-1,85)^{*}\end{array}$ \\
\hline Primary schools & $\begin{array}{c}-5,648 \\
(-2,02)^{* *}\end{array}$ & $\begin{array}{c}-5,335 \\
(-1,91)^{*}\end{array}$ & $\begin{array}{c}-5,642 \\
(-2,02)^{* *}\end{array}$ \\
\hline Secondary Schools & $\begin{array}{l}0,955 \\
(0,35)\end{array}$ & $\begin{array}{l}1,540 \\
(0,57)\end{array}$ & $\begin{array}{l}1,257 \\
(0,46)\end{array}$ \\
\hline Constant & $\begin{array}{l}0,006 \\
(0,37)\end{array}$ & $\begin{array}{l}0,005 \\
(0,29)\end{array}$ & $\begin{array}{c}0,002 \\
(0,10)\end{array}$ \\
\hline Election (year) & \multicolumn{3}{|c|}{ Dummy variable for each election \& year included } \\
\hline Wald $-\chi^{2}$ & 11465,92 & 11471,08 & 11471,78 \\
\hline $\mathrm{R}^{2}$ & 0.86 & 0.86 & 0.86 \\
\hline Nobs & 1960 & 1960 & 1960 \\
\hline
\end{tabular}


Table 4: Determinants of right wing extremist parties’ election performance: NPD, DVU and REP

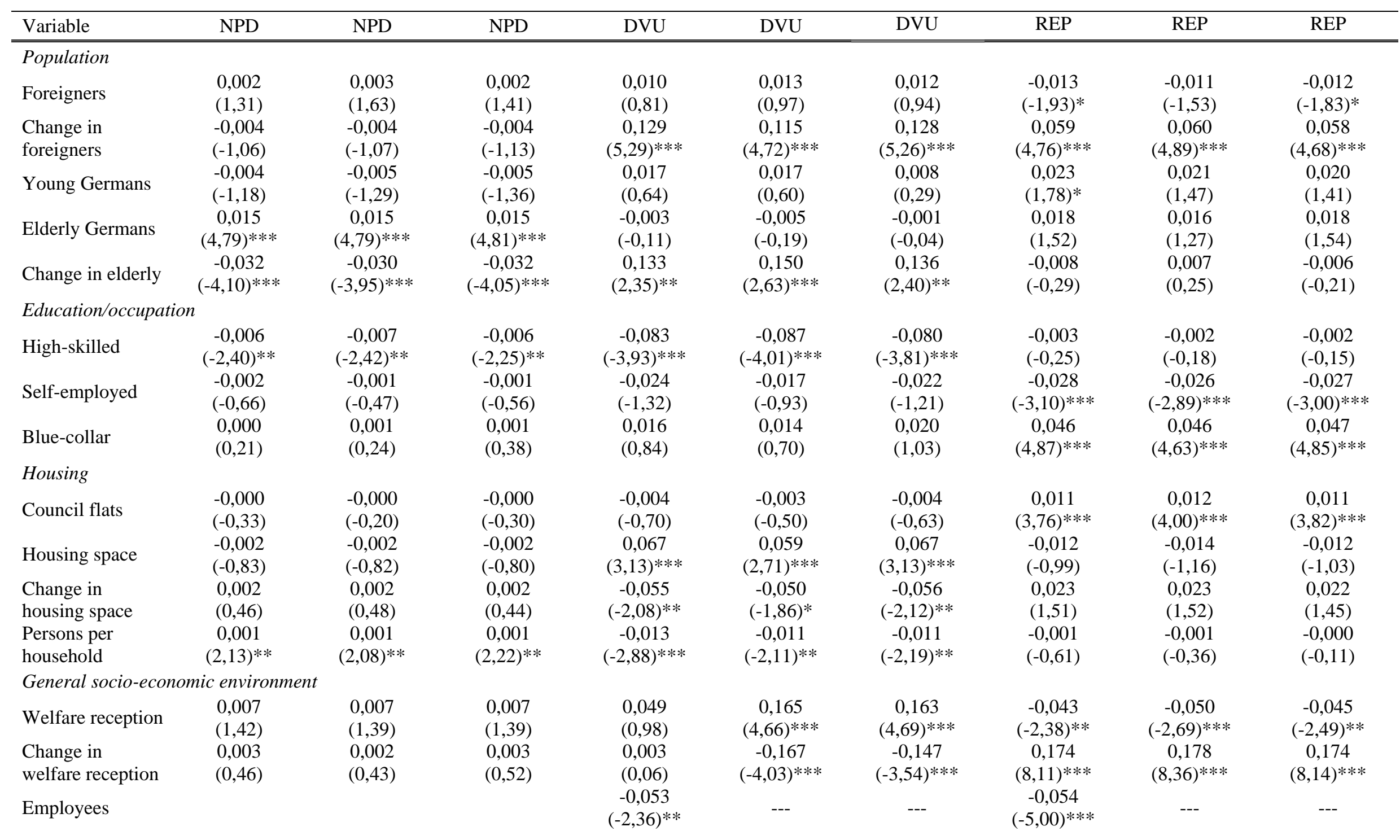




\begin{tabular}{|c|c|c|c|c|c|c|c|c|c|}
\hline $\begin{array}{l}\text { Female } \\
\text { employees }\end{array}$ & $\begin{array}{l}0,001 \\
(0,21)\end{array}$ & --- & --- & --- & $\begin{array}{l}-0,002 \\
(-0,09)\end{array}$ & $\begin{array}{l}-0,003 \\
(-0,12)\end{array}$ & --- & $\begin{array}{l}-0,016 \\
(-1,18)\end{array}$ & $\begin{array}{l}-0,016 \\
(-1,27)\end{array}$ \\
\hline Male employees & --- & $\begin{array}{l}0,003 \\
(0,79)\end{array}$ & $\begin{array}{l}0,002 \\
(0,73)\end{array}$ & --- & $\begin{array}{c}-0,049 \\
(-2,60)^{* * *}\end{array}$ & $\begin{array}{c}-0,040 \\
(-2,18)^{* *}\end{array}$ & --- & $\begin{array}{c}-0,033 \\
(-3,59)^{* * *}\end{array}$ & $\begin{array}{c}-0,034 \\
(-3,79)^{* * *}\end{array}$ \\
\hline \multicolumn{10}{|l|}{ Labour market } \\
\hline Unemployment & $\begin{array}{c}0,024 \\
(2,15)^{* *}\end{array}$ & $\begin{array}{c}0,024 \\
(2,07)^{* *}\end{array}$ & $\begin{array}{c}0,024 \\
(2,07)^{* *}\end{array}$ & $\begin{array}{l}-0,108 \\
(-1,26)\end{array}$ & $\begin{array}{c}-0,164 \\
(-1,83)^{*}\end{array}$ & $\begin{array}{l}-0,114 \\
(-1,31)\end{array}$ & $\begin{array}{c}-0,107 \\
(-2,44)^{* *}\end{array}$ & $\begin{array}{c}-0,102 \\
(-2,25)^{* *}\end{array}$ & $\begin{array}{c}-0,107 \\
(-2,40)^{* *}\end{array}$ \\
\hline $\begin{array}{l}\text { Change in } \\
\text { unemployment }\end{array}$ & $\begin{array}{c}0,024 \\
(1,92)^{*}\end{array}$ & $\begin{array}{c}0,025 \\
(2,00)^{* *}\end{array}$ & $\begin{array}{c}0,025 \\
(1,97)^{* *}\end{array}$ & $\begin{array}{c}0,542 \\
(5,74)^{* * *}\end{array}$ & $\begin{array}{c}0,542 \\
(5,67)^{* * *}\end{array}$ & $\begin{array}{c}0,538 \\
(5,70)^{* * *}\end{array}$ & $\begin{array}{c}0,098 \\
(2,00)^{* *}\end{array}$ & $\begin{array}{c}0,104 \\
(2,11)^{* *}\end{array}$ & $\begin{array}{c}0,098 \\
(2,00)^{* *}\end{array}$ \\
\hline $\begin{array}{l}\text { Youth } \\
\text { unemployment }\end{array}$ & $\begin{array}{c}-0,015 \\
(-1,92)^{*}\end{array}$ & $\begin{array}{c}-0,016 \\
(-1,97)^{* *}\end{array}$ & $\begin{array}{c}-0,015 \\
(-1,89)^{*}\end{array}$ & $\begin{array}{c}0,137 \\
(2,33)^{* *}\end{array}$ & $\begin{array}{c}0,157 \\
(2,62)^{* * *}\end{array}$ & $\begin{array}{c}0,140 \\
(2,39)^{* *}\end{array}$ & $\begin{array}{c}0,077 \\
(2,60)^{* * *}\end{array}$ & $\begin{array}{c}0,071 \\
(2,35)^{* *}\end{array}$ & $\begin{array}{c}0,077 \\
(2,61)^{* * *}\end{array}$ \\
\hline $\begin{array}{l}\text { Change in youth } \\
\text { unemployment }\end{array}$ & $\begin{array}{l}-0,000 \\
(-0,04)\end{array}$ & $\begin{array}{l}-0,000 \\
(-0,04)\end{array}$ & $\begin{array}{l}-0,001 \\
(-0,07)\end{array}$ & $\begin{array}{c}-0,164 \\
(-2,98)^{* * *}\end{array}$ & $\begin{array}{c}-0,165 \\
(-2,97)^{* * *}\end{array}$ & $\begin{array}{c}-0,162 \\
(-2,95)^{* * *}\end{array}$ & $\begin{array}{c}-0,065 \\
(-2,20)^{* *}\end{array}$ & $\begin{array}{c}-0,065 \\
(-2,18)^{* *}\end{array}$ & $\begin{array}{c}-0,065 \\
(-2,19)^{* *}\end{array}$ \\
\hline $\begin{array}{l}\text { Unemployment, } \\
\text { age 55-65 }\end{array}$ & $\begin{array}{l}-0,001 \\
(-0,20)\end{array}$ & $\begin{array}{l}-0,000 \\
(-0,06)\end{array}$ & $\begin{array}{l}-0,001 \\
(-0,16)\end{array}$ & $\begin{array}{c}-0,66 \\
(-1,30)\end{array}$ & $\begin{array}{l}-0,045 \\
(-0,87)\end{array}$ & $\begin{array}{l}-0,065 \\
(-1,28)\end{array}$ & $\begin{array}{l}0,023 \\
(0,88)\end{array}$ & $\begin{array}{l}0,020 \\
(0,78)\end{array}$ & $\begin{array}{l}0,022 \\
(0,86)\end{array}$ \\
\hline $\begin{array}{l}\text { Change in } \\
\text { unemployment, } \\
\text { age 55-65 }\end{array}$ & $\begin{array}{l}0,004 \\
(0,67)\end{array}$ & $\begin{array}{l}0,004 \\
(0,56)\end{array}$ & $\begin{array}{l}0,004 \\
(0,60)\end{array}$ & $\begin{array}{c}-0,096 \\
(-1,79)^{*}\end{array}$ & $\begin{array}{c}-0,093 \\
(-1,73)^{*}\end{array}$ & $\begin{array}{c}-0,094 \\
(-1,77)^{*}\end{array}$ & $\begin{array}{c}0,062 \\
(2,27)^{* *}\end{array}$ & $\begin{array}{c}0,055 \\
(2,01)^{* *}\end{array}$ & $\begin{array}{c}0,062 \\
(2,27)^{* *}\end{array}$ \\
\hline Wage & $\begin{array}{l}0,000 \\
(0,52)\end{array}$ & $\begin{array}{l}0,000 \\
(0,54)\end{array}$ & $\begin{array}{l}0,000 \\
(0,51)\end{array}$ & $\begin{array}{l}0,000 \\
(1,56)\end{array}$ & $\begin{array}{l}0,000 \\
(1,48)\end{array}$ & $\begin{array}{l}0,000 \\
(1,53)\end{array}$ & $\begin{array}{l}-0,000 \\
(-0,12)\end{array}$ & $\begin{array}{l}-0,000 \\
(-0,07)\end{array}$ & $\begin{array}{l}-0,000 \\
(-0,12)\end{array}$ \\
\hline \multicolumn{10}{|l|}{ Crime } \\
\hline Criminal acts & --- & $\begin{array}{l}0,000 \\
(0,81)\end{array}$ & --- & --- & $\begin{array}{l}-0,000 \\
(-0,22)\end{array}$ & --- & --- & $\begin{array}{c}0,000 \\
(2,36)^{* *}\end{array}$ & --- \\
\hline $\begin{array}{l}\text { Change in } \\
\text { Criminal acts }\end{array}$ & --- & $\begin{array}{c}-0,000 \\
(-1,98)^{* *}\end{array}$ & --- & --- & $\begin{array}{c}0,003 \\
(2,85)^{* * *}\end{array}$ & --- & --- & $\begin{array}{c}-0,003 \\
(-4,02)^{* * *}\end{array}$ & --- \\
\hline Thefts & $\begin{array}{l}0,000 \\
(0,45)\end{array}$ & --- & $\begin{array}{l}0,000 \\
(0,42)\end{array}$ & $\begin{array}{c}-0,000 \\
(-2,33)^{* *}\end{array}$ & --- & $\begin{array}{c}-0,000 \\
(-2,32)^{* *}\end{array}$ & $\begin{array}{l}0,000 \\
(1,36)\end{array}$ & --- & $\begin{array}{l}0,000 \\
(1,35)\end{array}$ \\
\hline Change in thefts & $\begin{array}{l}-0,000 \\
(-1,18)\end{array}$ & --- & $\begin{array}{l}-0,000 \\
(-1,16)\end{array}$ & $\begin{array}{c}0,006 \\
(4,02)^{* * *}\end{array}$ & --- & $\begin{array}{c}0,006 \\
(4,04)^{* * *}\end{array}$ & $\begin{array}{c}-0,002 \\
(-3,26)^{* * *}\end{array}$ & --- & $\begin{array}{c}-0,002 \\
(-3,28)^{* * *}\end{array}$ \\
\hline Violent crimes & $\begin{array}{l}0,000 \\
(0,39)\end{array}$ & --- & $\begin{array}{l}0,000 \\
(0,40)\end{array}$ & $\begin{array}{c}0,000 \\
(2,40)^{* *}\end{array}$ & --- & $\begin{array}{c}0,000 \\
(2,38)^{* *}\end{array}$ & $\begin{array}{l}0,000 \\
(0,84)\end{array}$ & --- & $\begin{array}{l}0,000 \\
(0,88)\end{array}$ \\
\hline $\begin{array}{l}\text { Change in violent } \\
\text { crimes } \\
\text { Infrastructure }\end{array}$ & $\begin{array}{l}-0,000 \\
(-1,27)\end{array}$ & --- & $\begin{array}{l}-0,000 \\
(-1,23)\end{array}$ & $\begin{array}{l}-0,000 \\
(-0,60)\end{array}$ & --- & $\begin{array}{l}-0,000 \\
(-0,52)\end{array}$ & $\begin{array}{l}-0,000 \\
(-0,28)\end{array}$ & --- & $\begin{array}{l}-0,000 \\
(-0,24)\end{array}$ \\
\hline Cars & $\begin{array}{l}-0,000 \\
(-0,87)\end{array}$ & $\begin{array}{l}-0,000 \\
(-1,01)\end{array}$ & $\begin{array}{l}-0,000 \\
(-0,98)\end{array}$ & $\begin{array}{c}0,000 \\
(3,57)^{* * *}\end{array}$ & $\begin{array}{c}0,000 \\
(2,81)^{* * *}\end{array}$ & $\begin{array}{c}0,000 \\
(3,43)^{* * *}\end{array}$ & $\begin{array}{l}0,000 \\
(1,43)\end{array}$ & $\begin{array}{l}0,000 \\
(1,14)\end{array}$ & $\begin{array}{l}0,000 \\
(1,26)\end{array}$ \\
\hline Kindergarten & $\begin{array}{l}-0,000 \\
(-0,07)\end{array}$ & $\begin{array}{l}-0,000 \\
(-0,07)\end{array}$ & $\begin{array}{l}-0,000 \\
(-0,18)\end{array}$ & $\begin{array}{l}-0,000 \\
(-0,94)\end{array}$ & $\begin{array}{l}-0,000 \\
(-1,14)\end{array}$ & $\begin{array}{l}-0,000 \\
(-1,10)\end{array}$ & $\begin{array}{l}-0,000 \\
(-1,15)\end{array}$ & $\begin{array}{l}-0,000 \\
(-0,99)\end{array}$ & $\begin{array}{l}-0,000 \\
(-1,29)\end{array}$ \\
\hline
\end{tabular}




\begin{tabular}{|c|c|c|c|c|c|c|c|c|c|}
\hline Primary schools & $\begin{array}{l}0,250 \\
(0,50)\end{array}$ & $\begin{array}{l}0,387 \\
(0,78)\end{array}$ & $\begin{array}{l}0,266 \\
(0,53)\end{array}$ & $\begin{array}{l}-5,993 \\
(-1,24)\end{array}$ & $\begin{array}{l}-6,548 \\
(-1,33)\end{array}$ & $\begin{array}{l}-6,106 \\
(-1,28)\end{array}$ & $\begin{array}{l}-3,200 \\
(-1,46)\end{array}$ & $\begin{array}{l}-2,570 \\
(-1,14)\end{array}$ & $\begin{array}{l}-3,217 \\
(-1,47)\end{array}$ \\
\hline Secondary & 0,285 & 0,245 & 0,298 & $-1,319$ & 0,666 & $-0,847$ & 1,471 & 1,536 & 1,700 \\
\hline Schools & $(0,53)$ & $(0,47)$ & $(0,55)$ & $(-0,30)$ & $(0,15)$ & $(-0,19)$ & $(0,71)$ & $(0,73)$ & $(0,82)$ \\
\hline Constant & $\begin{array}{l}-0,002 \\
(-0,68)\end{array}$ & $\begin{array}{l}-0,003 \\
(-0,83)\end{array}$ & $\begin{array}{l}-0,003 \\
(-0,87)\end{array}$ & $\begin{array}{l}0,026 \\
(1,09)\end{array}$ & $\begin{array}{l}0,030 \\
(1,23)\end{array}$ & $\begin{array}{l}0,019 \\
(0,78)\end{array}$ & $\begin{array}{c}0,022 \\
(1,87)^{*}\end{array}$ & $\begin{array}{c}0,020 \\
(1,66)^{*}\end{array}$ & $\begin{array}{l}0,019 \\
(1,58)\end{array}$ \\
\hline Election (year) & \multicolumn{9}{|c|}{ Dummy variable for each election \& year included } \\
\hline Wald $-\chi^{2}$ & 2135,05 & 2134,32 & 2130,50 & 2716,48 & 2659,00 & 2717,78 & 6774,25 & 6768,11 & 6775,91 \\
\hline $\mathrm{R}^{2}$ & 0.61 & 0.61 & 0.61 & 0.78 & 0.78 & 0.78 & 0.81 & 0.81 & 0.81 \\
\hline Nobs & 1274 & 1274 & 1274 & 784 & 784 & 784 & 1568 & 1568 & 1568 \\
\hline
\end{tabular}

Note: t-values in parantheses; $* * *, * *$ and * indicate statistical significance on the 1, 5 and 10 percent level, respectively (two-tailed test). 
Table 5: Determinants of right-wing populist parties’ election results: Partei Rechtsstaatlicher Offensive/Schill-Partei, Pro DM/Schill (Schill 2), Pro DM and Partei Rechtsstaatlicher Offensive (Offensive D)

\begin{tabular}{|c|c|c|c|c|c|c|c|c|c|c|c|c|}
\hline Variable & Schill & Schill & Schill & Schill 2 & Schill 2 & Schill 2 & Pro DM & Pro DM & Pro DM & $\begin{array}{c}\text { Offensive } \\
\mathrm{D} \\
\end{array}$ & $\begin{array}{c}\text { Offensive } \\
\mathrm{D} \\
\end{array}$ & $\begin{array}{c}\text { Offensive } \\
\mathrm{D} \\
\end{array}$ \\
\hline \multicolumn{13}{|l|}{ Population } \\
\hline Foreigners & $\begin{array}{l}-0,039 \\
(-0,59)\end{array}$ & $\begin{array}{l}-0,024 \\
(-0,35)\end{array}$ & $\begin{array}{l}-0,049 \\
(-0,69)\end{array}$ & $\begin{array}{l}0,054 \\
(1,19)\end{array}$ & $\begin{array}{l}0,039 \\
(0,85)\end{array}$ & $\begin{array}{l}0,049 \\
(1,06)\end{array}$ & $\begin{array}{l}-0,002 \\
(-0,72)\end{array}$ & $\begin{array}{l}-0,003 \\
(-1,21)\end{array}$ & $\begin{array}{l}-0,003 \\
(-1,22)\end{array}$ & $\begin{array}{l}0,006 \\
(0,50)\end{array}$ & $\begin{array}{l}0,003 \\
(0,23)\end{array}$ & $\begin{array}{l}0,004 \\
(0,30)\end{array}$ \\
\hline Change in foreigners & $\begin{array}{c}0,442 \\
(2,28)^{* *}\end{array}$ & $\begin{array}{c}0,442 \\
(2,42)^{* *}\end{array}$ & $\begin{array}{c}0,447 \\
(2,29)^{* *}\end{array}$ & $\begin{array}{c}0,270 \\
(2,64)^{* * *}\end{array}$ & $\begin{array}{c}0,294 \\
(3,07)^{* * *}\end{array}$ & $\begin{array}{c}0,271 \\
(2,63)^{* * *}\end{array}$ & $\begin{array}{l}-0,008 \\
(-1,22)\end{array}$ & $\begin{array}{l}-0,003 \\
(-0,51)\end{array}$ & $\begin{array}{l}-0,008 \\
(-1,24)\end{array}$ & $\begin{array}{c}0,103 \\
(3,80)^{* * *}\end{array}$ & $\begin{array}{c}0,101 \\
(4,04)^{* * *}\end{array}$ & $\begin{array}{c}0,101 \\
(3,74)^{* * *}\end{array}$ \\
\hline Young Germans & $\begin{array}{l}0,014 \\
(0,09)\end{array}$ & $\begin{array}{l}-0,076 \\
(-0,47)\end{array}$ & $\begin{array}{l}0,030 \\
(0,18)\end{array}$ & $\begin{array}{l}0,018 \\
(0,25)\end{array}$ & $\begin{array}{l}0,036 \\
(0,51)\end{array}$ & $\begin{array}{l}0,025 \\
(0,34)\end{array}$ & $\begin{array}{l}-0,004 \\
(-0,69)\end{array}$ & $\begin{array}{l}-0,003 \\
(-0,53)\end{array}$ & $\begin{array}{l}-0,001 \\
(-0,13)\end{array}$ & $\begin{array}{l}-0,009 \\
(-0,50)\end{array}$ & $\begin{array}{l}-0,007 \\
(-0,37)\end{array}$ & $\begin{array}{l}-0,008 \\
(-0,39)\end{array}$ \\
\hline Elderly Germans & $\begin{array}{l}0,141 \\
(0,96)\end{array}$ & $\begin{array}{l}0,137 \\
(0,94)\end{array}$ & $\begin{array}{l}0,142 \\
(0,96)\end{array}$ & $\begin{array}{l}-0,035 \\
(-0,56)\end{array}$ & $\begin{array}{l}-0,060 \\
(-0,94)\end{array}$ & $\begin{array}{l}-0,036 \\
(-0,55)\end{array}$ & $\begin{array}{l}0,006 \\
(1,23)\end{array}$ & $\begin{array}{l}0,005 \\
(0,88)\end{array}$ & $\begin{array}{l}0,005 \\
(0,91)\end{array}$ & $\begin{array}{c}0,037 \\
(2,22)^{* *}\end{array}$ & $\begin{array}{c}0,030 \\
(1,79)^{*}\end{array}$ & $\begin{array}{c}0,031 \\
(1,81)^{*}\end{array}$ \\
\hline Change in elderly & $\begin{array}{l}-0,009 \\
(-0,03)\end{array}$ & $\begin{array}{l}-0,061 \\
(-0,21)\end{array}$ & $\begin{array}{l}-0,003 \\
(-0,01)\end{array}$ & $\begin{array}{l}-0,157 \\
(-0,96)\end{array}$ & $\begin{array}{l}-0,215 \\
(-1,32)\end{array}$ & $\begin{array}{l}-0,156 \\
(-0,92)\end{array}$ & $\begin{array}{l}0,017 \\
(1,26)\end{array}$ & $\begin{array}{l}0,013 \\
(0,98)\end{array}$ & $\begin{array}{l}0,013 \\
(0,95)\end{array}$ & $\begin{array}{l}-0,045 \\
(-1,05)\end{array}$ & $\begin{array}{l}-0,031 \\
(-0,73)\end{array}$ & $\begin{array}{l}-0,031 \\
(-0,70)\end{array}$ \\
\hline \multicolumn{13}{|l|}{ Education/occupation } \\
\hline High-skilled & $\begin{array}{c}-0,451 \\
(-3,98)^{* * *}\end{array}$ & $\begin{array}{c}-0,421 \\
(-3,67)^{* * *}\end{array}$ & $\begin{array}{c}-0,458 \\
(-3,95) * * *\end{array}$ & $\begin{array}{l}0,018 \\
(0,35)\end{array}$ & $\begin{array}{l}-0,007 \\
(-0,13)\end{array}$ & $\begin{array}{l}0,012 \\
(0,21)\end{array}$ & $\begin{array}{l}-0,006 \\
(-1,29)\end{array}$ & $\begin{array}{l}-0,005 \\
(-1,10)\end{array}$ & $\begin{array}{c}-0,008 \\
(-1,74)^{*}\end{array}$ & $\begin{array}{c}0,028 \\
(2,03)^{* *}\end{array}$ & $\begin{array}{l}0,021 \\
(1,41)\end{array}$ & $\begin{array}{l}0,022 \\
(1,43)\end{array}$ \\
\hline Self-employed & $\begin{array}{l}0,009 \\
(0,09)\end{array}$ & $\begin{array}{l}0,013 \\
(0,13)\end{array}$ & $\begin{array}{l}0,003 \\
(0,03)\end{array}$ & $\begin{array}{c}-0,182 \\
(-3,65)^{* * *}\end{array}$ & $\begin{array}{c}-0,191 \\
(-4,10)^{* * *}\end{array}$ & $\begin{array}{c}-0,183 \\
(-3,61)^{* * *}\end{array}$ & $\begin{array}{l}0,002 \\
(0,53)\end{array}$ & $\begin{array}{l}-0,001 \\
(-0,23)\end{array}$ & $\begin{array}{l}0,001 \\
(0,23)\end{array}$ & $\begin{array}{l}0,005 \\
(0,35)\end{array}$ & $\begin{array}{l}0,006 \\
(0,53)\end{array}$ & $\begin{array}{l}0,007 \\
(0,52)\end{array}$ \\
\hline Blue-collar & $\begin{array}{l}-0,055 \\
(-0,56)\end{array}$ & $\begin{array}{l}-0,038 \\
(-0,39)\end{array}$ & $\begin{array}{l}-0,060 \\
(-0,61)\end{array}$ & $\begin{array}{l}0,016 \\
(0,43)\end{array}$ & $\begin{array}{l}0,005 \\
(0,12)\end{array}$ & $\begin{array}{l}0,012 \\
(0,30)\end{array}$ & $\begin{array}{l}0,001 \\
(0,23)\end{array}$ & $\begin{array}{l}0,002 \\
(0,60)\end{array}$ & $\begin{array}{l}-0,001 \\
(-0,24)\end{array}$ & $\begin{array}{c}0,037 \\
(3,71)^{* * *}\end{array}$ & $\begin{array}{c}0,033 \\
(3,08)^{* * *}\end{array}$ & $\begin{array}{c}0,032 \\
(3,05)^{* * *}\end{array}$ \\
\hline \multicolumn{13}{|l|}{ Housing } \\
\hline Council flats & $\begin{array}{l}0,055 \\
(1,48)\end{array}$ & $\begin{array}{l}0,049 \\
(1,34)\end{array}$ & $\begin{array}{l}0,055 \\
(1,50)\end{array}$ & $\begin{array}{l}0,011 \\
(0,65)\end{array}$ & $\begin{array}{l}0,009 \\
(0,50)\end{array}$ & $\begin{array}{l}0,011 \\
(0,65)\end{array}$ & $\begin{array}{c}-0,003 \\
(-2,52)^{* *}\end{array}$ & $\begin{array}{c}-0,004 \\
(-2,78)^{* * *}\end{array}$ & $\begin{array}{c}-0,003 \\
(-2,50)^{* *}\end{array}$ & $\begin{array}{l}0,001 \\
(0,12)\end{array}$ & $\begin{array}{l}-0,000 \\
(-0,08)\end{array}$ & $\begin{array}{l}-0,000 \\
(-0,08)\end{array}$ \\
\hline Housing space & $\begin{array}{l}0,120 \\
(0,97)\end{array}$ & $\begin{array}{l}0,146 \\
(1,23)\end{array}$ & $\begin{array}{l}0,119 \\
(0,97)\end{array}$ & $\begin{array}{c}-0,127 \\
(-2,21)^{* *}\end{array}$ & $\begin{array}{c}-0,118 \\
(-2,09)^{* *}\end{array}$ & $\begin{array}{c}-0,126 \\
(-2,19)^{* *}\end{array}$ & $\begin{array}{l}-0,006 \\
(-1,47)\end{array}$ & $\begin{array}{l}-0,004 \\
(-1,00)\end{array}$ & $\begin{array}{l}-0,006 \\
(-1,45)\end{array}$ & $\begin{array}{l}-0,009 \\
(-0,57)\end{array}$ & $\begin{array}{l}-0,006 \\
(-0,44)\end{array}$ & $\begin{array}{l}-0,008 \\
(-0,51)\end{array}$ \\
\hline Change in housing space & $\begin{array}{l}0,307 \\
(1,10)\end{array}$ & $\begin{array}{l}0,208 \\
(0,76)\end{array}$ & $\begin{array}{l}0,306 \\
(1,09)\end{array}$ & $\begin{array}{c}0,423 \\
(2,30)^{* *}\end{array}$ & $\begin{array}{c}0,518 \\
(3,09)^{* * *}\end{array}$ & $\begin{array}{c}0,424 \\
(2,26)^{* *}\end{array}$ & $\begin{array}{c}-0,016 \\
(-2,10)^{* *}\end{array}$ & $\begin{array}{c}-0,015 \\
(-1,97)^{* *}\end{array}$ & $\begin{array}{c}-0,014 \\
(-1,92)^{*}\end{array}$ & $\begin{array}{c}0,177 \\
(3,63)^{* * *}\end{array}$ & $\begin{array}{c}0,162 \\
(3,70)^{* * *}\end{array}$ & $\begin{array}{c}0,166 \\
(3,36)^{* * *}\end{array}$ \\
\hline Persons per household & $\begin{array}{l}-0,015 \\
(-0,62)\end{array}$ & $\begin{array}{l}-0,012 \\
(-0,39)\end{array}$ & $\begin{array}{l}-0,017 \\
(-0,54)\end{array}$ & $\begin{array}{l}-0,009 \\
(-0,84)\end{array}$ & $\begin{array}{l}-0,009 \\
(-0,72)\end{array}$ & $\begin{array}{l}-0,010 \\
(-0,74)\end{array}$ & $\begin{array}{l}-0,001 \\
(-1,57)\end{array}$ & $\begin{array}{c}-0,002 \\
(-1,97)^{* *}\end{array}$ & $\begin{array}{c}-0,003 \\
(-2,37)^{* *}\end{array}$ & $\begin{array}{c}0,005 \\
(1,89)^{*}\end{array}$ & $\begin{array}{l}0,003 \\
(0,82)\end{array}$ & $\begin{array}{l}0,003 \\
(0,83)\end{array}$ \\
\hline \multicolumn{13}{|c|}{ General socio-economic environment } \\
\hline Welfare reception & $\begin{array}{l}-0,017 \\
(-0,08)\end{array}$ & $\begin{array}{l}0,076 \\
(0,36)\end{array}$ & $\begin{array}{l}-0,013 \\
(-0,06)\end{array}$ & $\begin{array}{l}0,062 \\
(0,56)\end{array}$ & $\begin{array}{l}0,085 \\
(0,77)\end{array}$ & $\begin{array}{l}0,065 \\
(0,58)\end{array}$ & $\begin{array}{l}0,011 \\
(1,38)\end{array}$ & $\begin{array}{c}0,016 \\
(1,93)^{*}\end{array}$ & $\begin{array}{l}0,011 \\
(1,45)\end{array}$ & $\begin{array}{l}-0,023 \\
(-0,80)\end{array}$ & $\begin{array}{l}-0,015 \\
(-0,52)\end{array}$ & $\begin{array}{l}-0,020 \\
(-0,69)\end{array}$ \\
\hline $\begin{array}{l}\text { Change in welfare } \\
\text { reception }\end{array}$ & $\begin{array}{c}-0,550 \\
(-2,62)^{* * *}\end{array}$ & $\begin{array}{c}-0,549 \\
(-2,67)^{* * *}\end{array}$ & $\begin{array}{c}-0,554 \\
(-2,64)^{* * *}\end{array}$ & $\begin{array}{c}-0,498 \\
(-2,94)^{* * *}\end{array}$ & $\begin{array}{c}-0,465 \\
(-2,79)^{* * *}\end{array}$ & $\begin{array}{c}-0,502 \\
(-2,90)^{* * *}\end{array}$ & $\begin{array}{l}-0,007 \\
(-0,81)\end{array}$ & $\begin{array}{l}-0,015 \\
(-1,60)\end{array}$ & $\begin{array}{l}-0,010 \\
(-1,11)\end{array}$ & $\begin{array}{c}0,117 \\
(2,60)^{* * *}\end{array}$ & $\begin{array}{c}0,101 \\
(2,32)^{* *}\end{array}$ & $\begin{array}{c}0,106 \\
(2,33)^{* *}\end{array}$ \\
\hline Employees & $\begin{array}{c}-0,330 \\
(-2,76)^{* * *}\end{array}$ & --- & --- & $\begin{array}{l}-0,082 \\
(-1,27)\end{array}$ & --- & --- & $\begin{array}{l}0,000 \\
(0,10)\end{array}$ & --- & --- & $\begin{array}{l}-0,012 \\
(-0,69)\end{array}$ & --- & --- \\
\hline Female employees & --- & $\begin{array}{l}-0,078 \\
(-0,53)\end{array}$ & $\begin{array}{l}-0,177 \\
(-1,16)\end{array}$ & --- & $\begin{array}{l}-0,052 \\
(-0,79)\end{array}$ & $\begin{array}{l}-0,052 \\
(-0,73)\end{array}$ & --- & $\begin{array}{l}-0,005 \\
(-0,96)\end{array}$ & $\begin{array}{c}-0,010 \\
(-1,76)^{*}\end{array}$ & --- & $\begin{array}{l}-0,026 \\
(-1,54)\end{array}$ & $\begin{array}{l}-0,026 \\
(-1,38)\end{array}$ \\
\hline
\end{tabular}




\begin{tabular}{|c|c|c|c|c|c|c|c|c|c|c|c|c|}
\hline Male employees & --- & $\begin{array}{l}-0,154 \\
(-1,55)\end{array}$ & $\begin{array}{c}-0,173 \\
(-1,72)^{*}\end{array}$ & --- & $\begin{array}{l}-0,071 \\
(-1,28)\end{array}$ & $\begin{array}{l}-0,041 \\
(-0,70)\end{array}$ & --- & $\begin{array}{l}0,005 \\
(1,22)\end{array}$ & $\begin{array}{l}0,005 \\
(1,43)\end{array}$ & --- & $\begin{array}{l}0,007 \\
(0,46)\end{array}$ & $\begin{array}{l}0,009 \\
(0,56)\end{array}$ \\
\hline \multicolumn{13}{|l|}{ Labour market } \\
\hline Unemployment & $\begin{array}{c}-0,835 \\
(-1,69)^{*}\end{array}$ & $\begin{array}{c}-0,951 \\
(-1,85)^{*}\end{array}$ & $\begin{array}{c}-0,852 \\
(-1,69)^{*}\end{array}$ & $\begin{array}{l}-0,067 \\
(-0,22)\end{array}$ & $\begin{array}{l}-0,151 \\
(-0,51)\end{array}$ & $\begin{array}{l}-0,083 \\
(-0,27)\end{array}$ & $\begin{array}{l}0,026 \\
(1,27)\end{array}$ & $\begin{array}{l}0,018 \\
(0,83)\end{array}$ & $\begin{array}{l}0,030 \\
(1,46)\end{array}$ & $\begin{array}{l}-0,046 \\
(-0,57)\end{array}$ & $\begin{array}{l}-0,065 \\
(-0,84)\end{array}$ & $\begin{array}{l}-0,045 \\
(-0,56)\end{array}$ \\
\hline Change in unemployment & $\begin{array}{c}0,993 \\
(2,29)^{* *}\end{array}$ & $\begin{array}{c}0,957 \\
(2,21)^{* *}\end{array}$ & $\begin{array}{c}1,004 \\
(2,30)^{* *}\end{array}$ & $\begin{array}{c}0,821 \\
(2,65)^{* * *}\end{array}$ & $\begin{array}{c}0,900 \\
(2,90)^{* * *}\end{array}$ & $\begin{array}{c}0,826 \\
(2,64)^{* * *}\end{array}$ & $\begin{array}{l}-0,031 \\
(-1,54)\end{array}$ & $\begin{array}{l}-0,016 \\
(-0,80)\end{array}$ & $\begin{array}{l}-0,029 \\
(-1,43)\end{array}$ & $\begin{array}{c}0,137 \\
(1,67)^{*}\end{array}$ & $\begin{array}{l}0,133 \\
(1,64)\end{array}$ & $\begin{array}{l}0,124 \\
(1,51)\end{array}$ \\
\hline Youth unemployment & $\begin{array}{c}0,753 \\
(2,57)^{* *}\end{array}$ & $\begin{array}{c}0,752 \\
(2,61)^{* * *}\end{array}$ & $\begin{array}{c}0,747 \\
(2,55)^{* *}\end{array}$ & $\begin{array}{l}0,237 \\
(1,09)\end{array}$ & $\begin{array}{c}0,390 \\
(1,86)^{*}\end{array}$ & $\begin{array}{l}0,242 \\
(1,06)\end{array}$ & $\begin{array}{l}0,000 \\
(0,03)\end{array}$ & $\begin{array}{l}-0,001 \\
(-0,08)\end{array}$ & $\begin{array}{l}-0,005 \\
(-0,36)\end{array}$ & $\begin{array}{l}0,049 \\
(0,86)\end{array}$ & $\begin{array}{l}0,044 \\
(0,81)\end{array}$ & $\begin{array}{l}0,029 \\
(0,49)\end{array}$ \\
\hline $\begin{array}{l}\text { Change in youth } \\
\text { unemployment }\end{array}$ & $\begin{array}{c}-0,402 \\
(-1,92)^{*}\end{array}$ & $\begin{array}{c}-0,358 \\
(-1,73)^{*}\end{array}$ & $\begin{array}{c}-0,399 \\
(-1,91)^{*}\end{array}$ & $\begin{array}{l}-0,055 \\
(-0,32)\end{array}$ & $\begin{array}{l}-0,206 \\
(-1,18)\end{array}$ & $\begin{array}{l}-0,051 \\
(-0,26)\end{array}$ & $\begin{array}{l}0,016 \\
(1,45)\end{array}$ & $\begin{array}{l}0,014 \\
(1,23)\end{array}$ & $\begin{array}{l}0,017 \\
(1,53)\end{array}$ & $\begin{array}{l}-0,056 \\
(-1,24)\end{array}$ & $\begin{array}{l}-0,036 \\
(-0,78)\end{array}$ & $\begin{array}{l}-0,027 \\
(-0,52)\end{array}$ \\
\hline Unemployment, age 55-65 & $\begin{array}{c}0,635 \\
(2,36)^{* *}\end{array}$ & $\begin{array}{c}0,689 \\
(2,77)^{* * *}\end{array}$ & $\begin{array}{c}0,650 \\
(2,40)^{* *}\end{array}$ & $\begin{array}{l}0,167 \\
(1,02)\end{array}$ & $\begin{array}{l}0,130 \\
(0,84)\end{array}$ & $\begin{array}{l}0,177 \\
(1,06)\end{array}$ & $\begin{array}{c}-0,032 \\
(-3,33)^{* * *}\end{array}$ & $\begin{array}{c}-0,031 \\
(-3,17)^{* * *}\end{array}$ & $\begin{array}{c}-0,034 \\
(-3,52)^{* * *}\end{array}$ & $\begin{array}{c}0,108 \\
(2,47)^{* *}\end{array}$ & $\begin{array}{c}0,116 \\
(2,86)^{* * *}\end{array}$ & $\begin{array}{c}0,113 \\
(2,58)^{* * *}\end{array}$ \\
\hline $\begin{array}{l}\text { Change in unemployment, } \\
\text { age 55-65 }\end{array}$ & $\begin{array}{l}-0,262 \\
(-1,44)\end{array}$ & $\begin{array}{l}-0,283 \\
(-1,60)\end{array}$ & $\begin{array}{l}-0,267 \\
(-1,47)\end{array}$ & $\begin{array}{c}-0,365 \\
(-2,55)^{* *}\end{array}$ & $\begin{array}{c}-0,363 \\
\left(-2,73^{* * *}\right)\end{array}$ & $\begin{array}{c}-0,372 \\
(-2,60)^{* * *}\end{array}$ & $\begin{array}{c}0,035 \\
(3,49)^{* * *}\end{array}$ & $\begin{array}{c}0,035 \\
(3,43)^{* * *}\end{array}$ & $\begin{array}{c}0,036 \\
(3,59)^{* * *}\end{array}$ & $\begin{array}{c}0,067 \\
(1,78)^{*}\end{array}$ & $\begin{array}{c}0,064 \\
(1,84)^{*}\end{array}$ & $\begin{array}{c}0,067 \\
(1,78)^{*}\end{array}$ \\
\hline Wage & $\begin{array}{l}0,000 \\
(0,36)\end{array}$ & $\begin{array}{l}0,000 \\
(0,44)\end{array}$ & $\begin{array}{l}0,000 \\
(0,37)\end{array}$ & $\begin{array}{l}0,000 \\
(0,89)\end{array}$ & $\begin{array}{l}0,000 \\
(1,23)\end{array}$ & $\begin{array}{l}0,000 \\
(0,90)\end{array}$ & $\begin{array}{l}0,000 \\
(1,05)\end{array}$ & $\begin{array}{l}0,000 \\
(1,40)\end{array}$ & $\begin{array}{l}0,000 \\
(1,14)\end{array}$ & $\begin{array}{c}-0,000 \\
(-1,82)^{*}\end{array}$ & $\begin{array}{c}-0,000 \\
(-1,84)^{*}\end{array}$ & $\begin{array}{c}-0,000 \\
(-1,83)^{*}\end{array}$ \\
\hline \multicolumn{13}{|l|}{ Crime } \\
\hline Criminal acts & --- & $\begin{array}{l}0,000 \\
(1,24)\end{array}$ & --- & --- & $\begin{array}{l}-0,000 \\
(-0,18)\end{array}$ & --- & --- & $\begin{array}{l}0,000 \\
(1,45)\end{array}$ & --- & --- & $\begin{array}{l}0,000 \\
(1,51)\end{array}$ & --- \\
\hline Change in Criminal acts & --- & $\begin{array}{l}0,003 \\
(0,69)\end{array}$ & --- & --- & $\begin{array}{c}-0,006 \\
(-1,78)^{*}\end{array}$ & --- & --- & $\begin{array}{c}-0,001 \\
(-2,03)^{* *}\end{array}$ & --- & --- & $\begin{array}{l}-0,001 \\
(-1,47)\end{array}$ & --- \\
\hline Thefts & $\begin{array}{c}0,000 \\
(2,03)^{* *}\end{array}$ & --- & $\begin{array}{c}0,000 \\
(2,03)^{* *}\end{array}$ & $\begin{array}{l}-0,000 \\
(-0,10)\end{array}$ & --- & $\begin{array}{l}-0,000 \\
(-0,04)\end{array}$ & $\begin{array}{c}0,000 \\
(2,25)^{* *}\end{array}$ & --- & $\begin{array}{c}0,000 \\
(2,35)^{* *}\end{array}$ & $\begin{array}{l}-0,000 \\
(-0,00)\end{array}$ & --- & $\begin{array}{l}0,000 \\
(0,23)\end{array}$ \\
\hline Change in thefts & $\begin{array}{l}-0,003 \\
(-0,31)\end{array}$ & --- & $\begin{array}{l}-0,003 \\
(-0,31)\end{array}$ & $\begin{array}{l}-0,002 \\
(-1,15)\end{array}$ & --- & $\begin{array}{l}-0,003 \\
(-1,17)\end{array}$ & $\begin{array}{l}0,000 \\
(0,26)\end{array}$ & --- & $\begin{array}{l}0,000 \\
(0,21)\end{array}$ & $\begin{array}{l}-0,001 \\
(-0,99)\end{array}$ & --- & $\begin{array}{l}-0,001 \\
(-1,30)\end{array}$ \\
\hline Violent crimes & $\begin{array}{l}-0,001 \\
(-1,36)\end{array}$ & --- & $\begin{array}{l}-0,001 \\
(-1,34)\end{array}$ & $\begin{array}{l}-0,000 \\
(-0,02)\end{array}$ & --- & $\begin{array}{l}-0,000 \\
(-0,08)\end{array}$ & $\begin{array}{c}-0,000 \\
(-1,85)^{*}\end{array}$ & --- & $\begin{array}{c}-0,000 \\
(-1,83)^{*}\end{array}$ & $\begin{array}{l}0,000 \\
(0,89)\end{array}$ & --- & $\begin{array}{l}0,000 \\
(0,51)\end{array}$ \\
\hline Change in violent crimes & $\begin{array}{l}-0,002 \\
(-0,70)\end{array}$ & --- & $\begin{array}{l}-0,002 \\
(-0,68)\end{array}$ & $\begin{array}{l}0,003 \\
(1,51)\end{array}$ & --- & $\begin{array}{l}0,003 \\
(1,46)\end{array}$ & $\begin{array}{c}-0,000 \\
(-2,84)^{* * *}\end{array}$ & --- & $\begin{array}{c}-0,000 \\
(-3,29)^{* * *}\end{array}$ & $\begin{array}{l}-0,000 \\
(-0,33)\end{array}$ & --- & $\begin{array}{l}-0,000 \\
(-0,01)\end{array}$ \\
\hline \multicolumn{13}{|l|}{ Infrastructure } \\
\hline Cars & $\begin{array}{l}0,000 \\
(0,03)\end{array}$ & $\begin{array}{l}0,000 \\
(0,38)\end{array}$ & $\begin{array}{l}0,000 \\
(0,01)\end{array}$ & $\begin{array}{c}0,000 \\
(3,89)^{* * *}\end{array}$ & $\begin{array}{c}0,000 \\
(4,03)^{* * *}\end{array}$ & $\begin{array}{c}0,000 \\
(3,74)^{* * *}\end{array}$ & $\begin{array}{c}-0,000 \\
(-1,89)^{*}\end{array}$ & $\begin{array}{l}-0,000 \\
(-1,45)\end{array}$ & $\begin{array}{c}-0,000 \\
(-1,72)^{*}\end{array}$ & $\begin{array}{l}0,000 \\
(0,94)\end{array}$ & $\begin{array}{l}0,000 \\
(0,63)\end{array}$ & $\begin{array}{l}0,000 \\
(0,65)\end{array}$ \\
\hline Kindergarten & $\begin{array}{l}-0,000 \\
(-0,68)\end{array}$ & $\begin{array}{l}-0,000 \\
(-0,87)\end{array}$ & $\begin{array}{l}-0,000 \\
(-0,71)\end{array}$ & $\begin{array}{l}0,000 \\
(0,60)\end{array}$ & $\begin{array}{l}0,000 \\
(0,41)\end{array}$ & $\begin{array}{l}0,000 \\
(0,60)\end{array}$ & $\begin{array}{l}-0,000 \\
(-1,12)\end{array}$ & $\begin{array}{l}-0,000 \\
(-1,03)\end{array}$ & $\begin{array}{l}-0,000 \\
(-0,86)\end{array}$ & $\begin{array}{l}-0,000 \\
(-0,52)\end{array}$ & $\begin{array}{l}-0,000 \\
(-0,40)\end{array}$ & $\begin{array}{l}-0,000 \\
(-0,35)\end{array}$ \\
\hline Primary schools & $\begin{array}{l}-6,768 \\
(-0,36)\end{array}$ & $\begin{array}{l}-4,772 \\
(-0,25)\end{array}$ & $\begin{array}{l}-7,172 \\
(-0,37)\end{array}$ & $\begin{array}{l}-1,104 \\
(-0,14)\end{array}$ & $\begin{array}{l}-7,310 \\
(-1,06)\end{array}$ & $\begin{array}{l}-1,256 \\
(-0,16)\end{array}$ & $\begin{array}{l}-0,241 \\
(-0,26)\end{array}$ & $\begin{array}{l}-0,610 \\
(-0,65)\end{array}$ & $\begin{array}{l}-0,251 \\
(-0,27)\end{array}$ & $\begin{array}{l}2,531 \\
(1,21)\end{array}$ & $\begin{array}{l}2,412 \\
(1,33)\end{array}$ & $\begin{array}{l}2,638 \\
(1,26)\end{array}$ \\
\hline Secondary Schools & $\begin{array}{l}-3,809 \\
(-0,22)\end{array}$ & $\begin{array}{c}-10,511 \\
(-0,62)\end{array}$ & $\begin{array}{l}-4,026 \\
(-0,23)\end{array}$ & $\begin{array}{l}13,383 \\
(0,99)\end{array}$ & $\begin{array}{l}9,326 \\
(0,73)\end{array}$ & $\begin{array}{l}13,441 \\
(0,99)\end{array}$ & $\begin{array}{c}2,056 \\
(2,56)^{* *}\end{array}$ & $\begin{array}{c}1,434 \\
(1,81)^{*}\end{array}$ & $\begin{array}{c}1,841 \\
(2,29)^{* *}\end{array}$ & $\begin{array}{l}-0,261 \\
(-0,07)\end{array}$ & $\begin{array}{l}-0,306 \\
(-0,09)\end{array}$ & $\begin{array}{l}-0,164 \\
(-0,05)\end{array}$ \\
\hline Constant & $\begin{array}{c}0,392 \\
(3,03)^{* * *}\end{array}$ & $\begin{array}{c}0,330 \\
(2,36)^{* *}\end{array}$ & $\begin{array}{c}0,406 \\
(2,79)^{* * *}\end{array}$ & $\begin{array}{l}-0,016 \\
(-0,28)\end{array}$ & $\begin{array}{l}0,011 \\
(0,16)\end{array}$ & $\begin{array}{l}-0,007 \\
(-0,10)\end{array}$ & --- & $\begin{array}{c}0,10 \\
(1,93)^{*}\end{array}$ & --- & --- & $\begin{array}{l}-0,009 \\
(-0,48)\end{array}$ & --- \\
\hline Election (year) & & & & & Dummy v & able for eac & election \& y & Ir included & & & & \\
\hline
\end{tabular}




\begin{tabular}{|c|c|c|c|c|c|c|c|c|c|c|c|c|}
\hline Wald $-\chi^{2}$ & 3498,21 & 3452,94 & 3491,65 & 213,75 & 215,60 & 213,23 & 202,10 & 182,02 & 209,01 & 402,37 & 415,28 & 405,91 \\
\hline $\mathrm{R}^{2}$ & 0.94 & 0.94 & 0.94 & 0.37 & 0.37 & 0.37 & 0.57 & 0.53 & 0.59 & 0.39 & 0.39 & 0.39 \\
\hline Nobs & 294 & 294 & 294 & 196 & 196 & 196 & 196 & 196 & 196 & 196 & 196 & 196 \\
\hline
\end{tabular}

Note: t-values in parantheses; ***, ** and * indicate statistical significance on the 1, 5 and 10 percent level, respectively (two-tailed test). 
Table 6: Determinants of center-right and center-left parties' election performance: CDU and SPD

\begin{tabular}{|c|c|c|c|c|c|c|}
\hline Variable & CDU & $\mathrm{CDU}$ & CDU & SPD & SPD & SPD \\
\hline \multicolumn{7}{|l|}{ Popuation } \\
\hline Foreigners & $\begin{array}{c}0,209 \\
(9,28)^{* * *}\end{array}$ & $\begin{array}{c}0,203 \\
(9,10)^{* * *}\end{array}$ & $\begin{array}{c}0,208 \\
(9,30)^{* * *}\end{array}$ & $\begin{array}{c}-0,159 \\
(-6,54) * * *\end{array}$ & $\begin{array}{c}-0,158 \\
(-6,50)^{* * *}\end{array}$ & $\begin{array}{c}-0,158 \\
(-6,50) * * *\end{array}$ \\
\hline Change in foreigners & $\begin{array}{l}0,013 \\
(0,44)\end{array}$ & $\begin{array}{l}0,020 \\
(0,69)\end{array}$ & $\begin{array}{l}0,019 \\
(0,65)\end{array}$ & $\begin{array}{c}0,136 \\
(4,40)^{* * *}\end{array}$ & $\begin{array}{c}0,140 \\
(4,47)^{* * *}\end{array}$ & $\begin{array}{c}0,133 \\
(4,27)^{* * *}\end{array}$ \\
\hline Young Germans & $\begin{array}{c}-0,380 \\
(-6,07)^{* * *}\end{array}$ & $\begin{array}{c}-0,354 \\
(-5,45)^{* * *}\end{array}$ & $\begin{array}{c}-0,357 \\
(-5,70)^{* * *}\end{array}$ & $\begin{array}{l}0,019 \\
(0,26)\end{array}$ & $\begin{array}{l}0,051 \\
(0,67)\end{array}$ & $\begin{array}{l}0,003 \\
(0,04)\end{array}$ \\
\hline Elderly Germans & $\begin{array}{c}0,346 \\
(10,08)^{* * *}\end{array}$ & $\begin{array}{c}0,351 \\
(10,20)^{* * *}\end{array}$ & $\begin{array}{c}0,356 \\
(10,37)^{* * *}\end{array}$ & $\begin{array}{c}0,089 \\
(2,43)^{* *}\end{array}$ & $\begin{array}{c}0,080 \\
(2,16)^{* *}\end{array}$ & $\begin{array}{c}0,084 \\
(2,26)^{* *}\end{array}$ \\
\hline Change in elderly & $\begin{array}{l}-0,065 \\
(-0,89)\end{array}$ & $\begin{array}{l}-0,081 \\
(-1,12)\end{array}$ & $\begin{array}{l}-0,077 \\
(-1,05)\end{array}$ & $\begin{array}{l}0,039 \\
(0,50)\end{array}$ & $\begin{array}{l}0,040 \\
(0,51)\end{array}$ & $\begin{array}{l}0,045 \\
(0,58)\end{array}$ \\
\hline \multicolumn{7}{|l|}{ Education/occupation } \\
\hline High-skilled & $\begin{array}{c}-0,372 \\
(-8,00)^{* * *}\end{array}$ & $\begin{array}{c}-0,367 \\
(-7,76)^{* * *}\end{array}$ & $\begin{array}{c}-0,367 \\
(-7,97)^{* * *}\end{array}$ & $\begin{array}{l}-0,002 \\
(-0,04)\end{array}$ & $\begin{array}{l}-0,015 \\
(-0,27)\end{array}$ & $\begin{array}{l}-0,003 \\
(-0,05)\end{array}$ \\
\hline Self-employed & $\begin{array}{c}0,800 \\
(17,07)^{* * *}\end{array}$ & $\begin{array}{c}0,798 \\
(16,66)^{* * *}\end{array}$ & $\begin{array}{c}0,808 \\
(17,41)^{* * *}\end{array}$ & $\begin{array}{c}-0,782 \\
(-14,23)^{* * *}\end{array}$ & $\begin{array}{c}-0,769 \\
(-13,61)^{* * *}\end{array}$ & $\begin{array}{c}-0,785 \\
(-14,37)^{* * *}\end{array}$ \\
\hline Blue-collar & $\begin{array}{c}-0,371 \\
(-8,37)^{* * *}\end{array}$ & $\begin{array}{c}-0,380 \\
(-8,35)^{* * *}\end{array}$ & $\begin{array}{c}-0,376 \\
(-8,50)^{* * *}\end{array}$ & $\begin{array}{c}0,283 \\
(5,56)^{* * *}\end{array}$ & $\begin{array}{c}0,277 \\
(5,28)^{* * *}\end{array}$ & $\begin{array}{c}0,288 \\
(5,66)^{* * *}\end{array}$ \\
\hline \multicolumn{7}{|l|}{ Housing } \\
\hline Council flats & $\begin{array}{l}-0,001 \\
(-0,06)\end{array}$ & $\begin{array}{l}-0,002 \\
(-0,20)\end{array}$ & $\begin{array}{l}-0,001 \\
(-0,13)\end{array}$ & $\begin{array}{c}0,055 \\
(5,75)^{* * *}\end{array}$ & $\begin{array}{c}0,056 \\
(5,83)^{* * *}\end{array}$ & $\begin{array}{c}0,055 \\
(5,78)^{* * *}\end{array}$ \\
\hline Housing space & $\begin{array}{c}0,075 \\
(2,12)^{* *}\end{array}$ & $\begin{array}{c}0,072 \\
(2,01)^{* *}\end{array}$ & $\begin{array}{c}0,068 \\
(1,92)^{*}\end{array}$ & $\begin{array}{l}0,052 \\
(1,37)\end{array}$ & $\begin{array}{l}0,059 \\
(1,53)\end{array}$ & $\begin{array}{l}0,056 \\
(1,47)\end{array}$ \\
\hline Change in housing space & $\begin{array}{l}0,002 \\
(0,06)\end{array}$ & $\begin{array}{l}0,004 \\
(0,10)\end{array}$ & $\begin{array}{l}0,008 \\
(0,22)\end{array}$ & $\begin{array}{c}-0,078 \\
(-1,96)^{*}\end{array}$ & $\begin{array}{c}-0,070 \\
(-1,76)^{*}\end{array}$ & $\begin{array}{c}-0,081 \\
(-2,04)^{* *}\end{array}$ \\
\hline Persons per household & $\begin{array}{c}0,064 \\
(5,53)^{* * *}\end{array}$ & $\begin{array}{c}0,058 \\
(4,76)^{* * *}\end{array}$ & $\begin{array}{c}0,058 \\
(4,94)^{* * *}\end{array}$ & $\begin{array}{l}0,004 \\
(0,32)\end{array}$ & $\begin{array}{l}0,007 \\
(0,45)\end{array}$ & $\begin{array}{l}0,008 \\
(0,59)\end{array}$ \\
\hline \multicolumn{7}{|c|}{ General socio-economic environment } \\
\hline Welfare reception & $\begin{array}{l}0,049 \\
(0,98)\end{array}$ & $\begin{array}{l}0,035 \\
(0,71)\end{array}$ & $\begin{array}{l}0,053 \\
(1,06)\end{array}$ & $\begin{array}{c}-0,594 \\
(-11,13)^{* * *}\end{array}$ & $\begin{array}{c}-0,595 \\
(-11,14)^{* * *}\end{array}$ & $\begin{array}{c}-0,595 \\
(-11,15)^{* * *}\end{array}$ \\
\hline Change in welfare reception & $\begin{array}{l}0,003 \\
(0,06)\end{array}$ & $\begin{array}{l}0,012 \\
(0,23)\end{array}$ & $\begin{array}{l}0,005 \\
(0,09)\end{array}$ & $\begin{array}{c}0,548 \\
(9,96)^{* * *}\end{array}$ & $\begin{array}{c}0,547 \\
(9,96)^{* * *}\end{array}$ & $\begin{array}{c}0,547 \\
(9,94)^{* * *}\end{array}$ \\
\hline Employees & $\begin{array}{c}0,227 \\
(6,06)^{* * *}\end{array}$ & --- & --- & $\begin{array}{c}-0,114 \\
(-2,79)^{* * *}\end{array}$ & --- & --- \\
\hline Female employees & --- & $\begin{array}{l}0,014 \\
(0,35)\end{array}$ & $\begin{array}{l}0,030 \\
(0,76)\end{array}$ & --- & $\begin{array}{l}-0,008 \\
(-0,19)\end{array}$ & $\begin{array}{l}-0,005 \\
(-0,12)\end{array}$ \\
\hline Male employees & --- & $\begin{array}{c}0,201 \\
(5,42)^{* * *}\end{array}$ & $\begin{array}{c}0,192 \\
(5,23)^{* * *}\end{array}$ & --- & $\begin{array}{c}-0,104 \\
(-2,53)^{* *}\end{array}$ & $\begin{array}{c}-0,101 \\
(-2,47)^{* *}\end{array}$ \\
\hline \multicolumn{7}{|l|}{ Labour market } \\
\hline Unemployment & $\begin{array}{l}0,153 \\
(1,29)\end{array}$ & $\begin{array}{c}0,207 \\
(1,75)^{*}\end{array}$ & $\begin{array}{l}0,178 \\
(1,49)\end{array}$ & $\begin{array}{c}0,674 \\
(5,30)^{* * *}\end{array}$ & $\begin{array}{c}0,674 \\
(5,30)^{* * *}\end{array}$ & $\begin{array}{c}0,658 \\
(5,14)^{* * *}\end{array}$ \\
\hline Change in unemployment & $\begin{array}{l}-0,015 \\
(-0,12)\end{array}$ & $\begin{array}{l}-0,035 \\
(-0,29)\end{array}$ & $\begin{array}{l}-0,017 \\
(-0,14)\end{array}$ & $\begin{array}{c}-0,624 \\
(-4,83)^{* * *}\end{array}$ & $\begin{array}{c}-0,653 \\
(-5,02)^{* * *}\end{array}$ & $\begin{array}{c}-0,621 \\
(-4,81)^{* * *}\end{array}$ \\
\hline Youth unemployment & $\begin{array}{l}0,050 \\
(0,63)\end{array}$ & $\begin{array}{l}0,049 \\
(0,63)\end{array}$ & $\begin{array}{l}0,052 \\
(0,66)\end{array}$ & $\begin{array}{l}-0,013 \\
(-0,15)\end{array}$ & $\begin{array}{l}0,009 \\
(0,11)\end{array}$ & $\begin{array}{l}-0,017 \\
(-0,20)\end{array}$ \\
\hline $\begin{array}{l}\text { Change in youth } \\
\text { unemployment }\end{array}$ & $\begin{array}{l}-0,021 \\
(-0,30)\end{array}$ & $\begin{array}{l}-0,016 \\
(-0,22)\end{array}$ & $\begin{array}{l}-0,024 \\
(-0,34)\end{array}$ & $\begin{array}{l}0,049 \\
(0,65)\end{array}$ & $\begin{array}{l}0,034 \\
(0,44)\end{array}$ & $\begin{array}{l}0,053 \\
(0,69)\end{array}$ \\
\hline Unemployment, age 55-65 & $\begin{array}{l}0,002 \\
(0,03)\end{array}$ & $\begin{array}{l}0,001 \\
(0,02)\end{array}$ & $\begin{array}{l}0,002 \\
(0,03)\end{array}$ & $\begin{array}{l}-0,037 \\
(-0,49)\end{array}$ & $\begin{array}{l}-0,015 \\
(-0,21)\end{array}$ & $\begin{array}{l}-0,036 \\
(-0,49)\end{array}$ \\
\hline $\begin{array}{l}\text { Change in unemployment, } \\
\text { age } 55-65\end{array}$ & $\begin{array}{l}-0,068 \\
(-1,01)\end{array}$ & $\begin{array}{l}-0,056 \\
(-0,83)\end{array}$ & $\begin{array}{l}-0,071 \\
(-1,05)\end{array}$ & $\begin{array}{c}0,181 \\
(2,53)^{* *}\end{array}$ & $\begin{array}{c}0,195 \\
(2,71)^{* * *}\end{array}$ & $\begin{array}{c}0,182 \\
(2,55)^{* *}\end{array}$ \\
\hline Wage & $\begin{array}{c}0,000 \\
(2,89)^{* * *}\end{array}$ & $\begin{array}{c}0,000 \\
(2,87)^{* * *}\end{array}$ & $\begin{array}{c}0,000 \\
(2,95)^{* * *}\end{array}$ & $\begin{array}{l}-0,000 \\
(-1,54)\end{array}$ & $\begin{array}{l}-0,000 \\
(-1,29)\end{array}$ & $\begin{array}{l}-0,000 \\
(-1,55)\end{array}$ \\
\hline
\end{tabular}




\begin{tabular}{|c|c|c|c|c|c|c|}
\hline \multicolumn{7}{|l|}{ Crime } \\
\hline Criminal acts & --- & $\begin{array}{c}-0,000 \\
(-4,41)^{* * *}\end{array}$ & --- & --- & $\begin{array}{l}-0,000 \\
(-1,22)\end{array}$ & --- \\
\hline Change in Criminal acts & --- & $\begin{array}{l}0,002 \\
(1,52)\end{array}$ & --- & --- & $\begin{array}{c}0,004 \\
(2,70)^{* * *}\end{array}$ & --- \\
\hline Thefts & $\begin{array}{l}-0,000 \\
(-0,61)\end{array}$ & --- & $\begin{array}{l}-0,000 \\
(-0,69)\end{array}$ & $\begin{array}{c}0,000 \\
(3,09)^{* * *}\end{array}$ & --- & $\begin{array}{c}0,000 \\
(3,16)^{* * *}\end{array}$ \\
\hline Change in thefts & $\begin{array}{l}0,001 \\
(0,86)\end{array}$ & --- & $\begin{array}{l}0,002 \\
(1,08)\end{array}$ & $\begin{array}{c}0,007 \\
(4,87)^{* * *}\end{array}$ & --- & $\begin{array}{c}0,007 \\
(4,74)^{* * *}\end{array}$ \\
\hline Violent crimes & $\begin{array}{c}-0,000 \\
(-3,20)^{* * *}\end{array}$ & --- & $\begin{array}{c}-0,000 \\
(-3,19)^{* * *}\end{array}$ & $\begin{array}{l}-0,000 \\
(-0,58)\end{array}$ & --- & $\begin{array}{l}-0,000 \\
(-0,63)\end{array}$ \\
\hline Change in violent crimes & $\begin{array}{l}0,000 \\
(0,65)\end{array}$ & --- & $\begin{array}{l}0,000 \\
(0,50)\end{array}$ & $\begin{array}{l}0,001 \\
(0,64)\end{array}$ & --- & $\begin{array}{l}0,001 \\
(0,71)\end{array}$ \\
\hline \multicolumn{7}{|l|}{ Infrastructure } \\
\hline Cars & $\begin{array}{l}-0,000 \\
(-0,79)\end{array}$ & $\begin{array}{l}-0,000 \\
(-0,31)\end{array}$ & $\begin{array}{l}-0,000 \\
(-0,58)\end{array}$ & $\begin{array}{l}-0,000 \\
(-0,63)\end{array}$ & $\begin{array}{l}-0,000 \\
(-0,44)\end{array}$ & $\begin{array}{l}-0,000 \\
(-0,73)\end{array}$ \\
\hline Kindergarten & $\begin{array}{c}-0,000 \\
(-3,87)^{* * *}\end{array}$ & $\begin{array}{c}-0,000 \\
(-3,56)^{* * *}\end{array}$ & $\begin{array}{c}-0,000 \\
(-3,53)^{* * *}\end{array}$ & $\begin{array}{l}-0,000 \\
(-0,26)\end{array}$ & $\begin{array}{l}-0,000 \\
(-0,39)\end{array}$ & $\begin{array}{l}-0,000 \\
(-0,40)\end{array}$ \\
\hline Primary schools & $\begin{array}{l}-0,128 \\
(-0,01)\end{array}$ & $\begin{array}{l}-2,093 \\
(-0,24)\end{array}$ & $\begin{array}{l}-1,842 \\
(-0,21)\end{array}$ & $\begin{array}{c}-23,980 \\
(-2,46)^{* *}\end{array}$ & $\begin{array}{c}-16,230 \\
(-1,63)\end{array}$ & $\begin{array}{c}-22,666 \\
(-2,32)^{* *}\end{array}$ \\
\hline Secondary Schools & $\begin{array}{l}-9,711 \\
(-1,50)\end{array}$ & $\begin{array}{l}-12,306 \\
(-1,90)^{*}\end{array}$ & $\begin{array}{l}-10,850 \\
(-1,68)^{*}\end{array}$ & $\begin{array}{c}34,049 \\
(4,89) * * *\end{array}$ & $\begin{array}{c}30,945 \\
(4,40)^{* * *}\end{array}$ & $\begin{array}{c}34,648 \\
(4,97)^{* * *}\end{array}$ \\
\hline Constant & $\begin{array}{c}0,111 \\
(2,33)^{* *}\end{array}$ & $\begin{array}{c}0,115 \\
(2,39)^{* *}\end{array}$ & $\begin{array}{c}0,112 \\
(2,38)^{* *}\end{array}$ & $\begin{array}{c}0,385 \\
(7,12)^{* * *}\end{array}$ & $\begin{array}{c}0,374 \\
(6,76)^{* * *}\end{array}$ & $\begin{array}{c}0,380 \\
(7,07)^{* * *}\end{array}$ \\
\hline Election (year) & \multicolumn{6}{|c|}{ Dummy variable for each election \& year included } \\
\hline Wald $-\chi^{2}$ & 21007,83 & 21086,72 & 21090,57 & 12522,11 & 12316,70 & 12526,08 \\
\hline $\mathrm{R}^{2}$ & 0.90 & 0.90 & 0.90 & 0.84 & 0.84 & 0.84 \\
\hline Nobs & 2352 & 2352 & 2352 & 2352 & 2352 & 2352 \\
\hline
\end{tabular}


Table 7: Determinants of left-wing and center-right populist parties' election performance: PDS and STATT Partei

\begin{tabular}{|c|c|c|c|c|c|c|}
\hline Variable & PDS & PDS & PDS & STATT & STATT & STATT \\
\hline \multicolumn{7}{|l|}{ Population } \\
\hline Foreigners & $\begin{array}{c}-0,027 \\
(-3,42)^{* * *}\end{array}$ & $\begin{array}{c}-0,027 \\
(-3,31)^{* * *}\end{array}$ & $\begin{array}{c}-0,026 \\
(-3,15)^{* * *}\end{array}$ & $\begin{array}{l}-0,007 \\
(-0,54)\end{array}$ & $\begin{array}{l}-0,006 \\
(-0,46)\end{array}$ & $\begin{array}{l}-0,005 \\
(-0,35)\end{array}$ \\
\hline Change in foreigners & $\begin{array}{l}-0,016 \\
(-1,33)\end{array}$ & $\begin{array}{c}-0,020 \\
(-1,70)^{*}\end{array}$ & $\begin{array}{l}-0,018 \\
(-1,47)\end{array}$ & $\begin{array}{c}-0,078 \\
(-3,76)^{* * *}\end{array}$ & $\begin{array}{c}-0,087 \\
(-4,15)^{* * *}\end{array}$ & $\begin{array}{c}-0,081 \\
(-3,88)^{* * *}\end{array}$ \\
\hline Young Germans & $\begin{array}{l}0,021 \\
(1,28)\end{array}$ & $\begin{array}{l}0,009 \\
(0,52)\end{array}$ & $\begin{array}{l}0,012 \\
(0,67)\end{array}$ & $\begin{array}{l}-0,024 \\
(-0,88)\end{array}$ & $\begin{array}{l}-0,040 \\
(-1,31)\end{array}$ & $\begin{array}{l}-0,032 \\
(-1,12)\end{array}$ \\
\hline Elderly Germans & $\begin{array}{c}-0,076 \\
(-5,39)^{* * *}\end{array}$ & $\begin{array}{c}-0,074 \\
(-5,21)^{* * *}\end{array}$ & $\begin{array}{c}-0,076 \\
(-5,39)^{* * *}\end{array}$ & $\begin{array}{l}-0,039 \\
(-1,61)\end{array}$ & $\begin{array}{l}-0,031 \\
(-1,19)\end{array}$ & $\begin{array}{l}-0,037 \\
(-1,53)\end{array}$ \\
\hline Change in elderly & $\begin{array}{l}-0,018 \\
(-0,62)\end{array}$ & $\begin{array}{l}-0,010 \\
(-0,36)\end{array}$ & $\begin{array}{l}-0,017 \\
(-0,57)\end{array}$ & $\begin{array}{l}-0,055 \\
(-1,04)\end{array}$ & $\begin{array}{l}-0,062 \\
(-1,18)\end{array}$ & $\begin{array}{l}-0,053 \\
(-1,01)\end{array}$ \\
\hline \multicolumn{7}{|l|}{ Education/occupation } \\
\hline High-skilled & $\begin{array}{l}0,015 \\
(1,12)\end{array}$ & $\begin{array}{l}0,022 \\
(1,63)\end{array}$ & $\begin{array}{l}0,019 \\
(1,38)\end{array}$ & $\begin{array}{c}-0,056 \\
(-2,52)^{* *}\end{array}$ & $\begin{array}{c}-0,058 \\
(-2,38)^{* *}\end{array}$ & $\begin{array}{c}-0,056 \\
(-2,49) * *\end{array}$ \\
\hline Self-employed & $\begin{array}{l}0,005 \\
(0,38)\end{array}$ & $\begin{array}{l}0,010 \\
(0,88)\end{array}$ & $\begin{array}{l}0,006 \\
(0,49)\end{array}$ & $\begin{array}{c}-0,058 \\
(-3,28)^{* * *}\end{array}$ & $\begin{array}{c}-0,055 \\
(-2,92)^{* * *}\end{array}$ & $\begin{array}{c}-0,056 \\
(-3,15)^{* * *}\end{array}$ \\
\hline Blue-collar & $\begin{array}{c}0,022 \\
(1,80)^{*}\end{array}$ & $\begin{array}{c}0,030 \\
(2,40)^{* *}\end{array}$ & $\begin{array}{c}0,027 \\
(2,12)^{* *}\end{array}$ & $\begin{array}{c}-0,044 \\
(-2,34)^{* *}\end{array}$ & $\begin{array}{l}-0,033 \\
(-1,58)\end{array}$ & $\begin{array}{c}-0,041 \\
(-2,09)^{* *}\end{array}$ \\
\hline \multicolumn{7}{|l|}{ Housing } \\
\hline Council flats & $\begin{array}{c}-0,014 \\
(-4,20)^{* * *}\end{array}$ & $\begin{array}{c}-0,014 \\
(-4,10)^{* * *}\end{array}$ & $\begin{array}{c}-0,014 \\
(-4,10)^{* * *}\end{array}$ & $\begin{array}{c}-0,013 \\
(-2,32)^{* *}\end{array}$ & $\begin{array}{c}-0,012 \\
(-2,14)^{* *}\end{array}$ & $\begin{array}{c}-0,012 \\
(-2,15)^{* *}\end{array}$ \\
\hline Housing space & $\begin{array}{l}-0,014 \\
(-0,99)\end{array}$ & $\begin{array}{l}-0,021 \\
(-1,48)\end{array}$ & $\begin{array}{l}-0,014 \\
(-0,98)\end{array}$ & $\begin{array}{l}0,009 \\
(0,42)\end{array}$ & $\begin{array}{c}0,005 \\
(0,23)\end{array}$ & $\begin{array}{l}0,009 \\
(0,40)\end{array}$ \\
\hline Change in housing space & $\begin{array}{l}0,007 \\
(0,47)\end{array}$ & $\begin{array}{l}0,006 \\
(0,41)\end{array}$ & $\begin{array}{l}0,006 \\
(0,40)\end{array}$ & $\begin{array}{l}-0,040 \\
(-1,63)\end{array}$ & $\begin{array}{c}-0,052 \\
(-2,12)^{* *}\end{array}$ & $\begin{array}{c}-0,043 \\
(-1,76)^{*}\end{array}$ \\
\hline Persons per household & $\begin{array}{c}-0,011 \\
(-3,80)^{* * *}\end{array}$ & $\begin{array}{c}-0,009 \\
(-2,94)^{* * *}\end{array}$ & $\begin{array}{c}-0,009 \\
(-2,99)^{* * *}\end{array}$ & $\begin{array}{l}-0,002 \\
(-0,54)\end{array}$ & $\begin{array}{l}-0,000 \\
(-0,03)\end{array}$ & $\begin{array}{l}-0,000 \\
(-0,01)\end{array}$ \\
\hline \multicolumn{7}{|c|}{ General socio-economic environment } \\
\hline Welfare reception & $\begin{array}{c}0,059 \\
(2,81)^{* * *}\end{array}$ & $\begin{array}{c}0,059 \\
(2,76)^{* * *}\end{array}$ & $\begin{array}{c}0,059 \\
(2,78)^{* * *}\end{array}$ & $\begin{array}{l}0,051 \\
(1,28)\end{array}$ & $\begin{array}{l}0,054 \\
(1,30)\end{array}$ & $\begin{array}{l}0,048 \\
(1,20)\end{array}$ \\
\hline Change in welfare reception & $\begin{array}{c}-0,113 \\
(-5,35)^{* * *}\end{array}$ & $\begin{array}{c}-0,114 \\
(-5,39)^{* * *}\end{array}$ & $\begin{array}{c}-0,112 \\
(-5,29)^{* * *}\end{array}$ & $\begin{array}{c}-0,137 \\
(-3,24)^{* * *}\end{array}$ & $\begin{array}{c}-0,144 \\
(-3,34)^{* * *}\end{array}$ & $\begin{array}{c}-0,142 \\
(-3,32)^{* * *}\end{array}$ \\
\hline Employees & $\begin{array}{c}-0,034 \\
(-2,70)^{* * *}\end{array}$ & --- & --- & $\begin{array}{l}-0,010 \\
(-0,44)\end{array}$ & --- & --- \\
\hline Female employees & --- & $\begin{array}{l}0,006 \\
(0,44)\end{array}$ & $\begin{array}{l}0,004 \\
(0,30)\end{array}$ & --- & $\begin{array}{l}0,033 \\
(1,25)\end{array}$ & $\begin{array}{l}0,021 \\
(0,81)\end{array}$ \\
\hline Male employees & --- & $\begin{array}{c}-0,031 \\
(-2,70) * * *\end{array}$ & $\begin{array}{c}-0,028 \\
(-2,48)^{* *}\end{array}$ & --- & $\begin{array}{l}-0,030 \\
(-1,48)\end{array}$ & $\begin{array}{l}-0,024 \\
(-1,26)\end{array}$ \\
\hline \multicolumn{7}{|l|}{ Labour market } \\
\hline Unemployment & $\begin{array}{c}0,114 \\
(2,27)^{* *}\end{array}$ & $\begin{array}{c}0,095 \\
(1,87)^{*}\end{array}$ & $\begin{array}{c}0,110 \\
(2,16)^{* *}\end{array}$ & $\begin{array}{l}-0,056 \\
(-0,61)\end{array}$ & $\begin{array}{l}-0,127 \\
(-1,25)\end{array}$ & $\begin{array}{l}-0,081 \\
(-0,85)\end{array}$ \\
\hline Change in unemployment & $\begin{array}{c}0,083 \\
(1,76)^{*}\end{array}$ & $\begin{array}{c}0,096 \\
(2,02)^{* *}\end{array}$ & $\begin{array}{c}0,084 \\
(1,78)^{*}\end{array}$ & $\begin{array}{l}-0,057 \\
(-0,60)\end{array}$ & $\begin{array}{l}0,003 \\
(0,03)\end{array}$ & $\begin{array}{l}-0,048 \\
(-0,50)\end{array}$ \\
\hline Youth unemployment & $\begin{array}{c}-0,079 \\
(-2,38)^{* *}\end{array}$ & $\begin{array}{c}-0,080 \\
(-2,41)^{* *}\end{array}$ & $\begin{array}{c}-0,082 \\
(-2,46)^{* *}\end{array}$ & $\begin{array}{l}0,015 \\
(0,25)\end{array}$ & $\begin{array}{l}0,043 \\
(0,66)\end{array}$ & $\begin{array}{l}0,027 \\
(0,43)\end{array}$ \\
\hline $\begin{array}{l}\text { Change in youth } \\
\text { unemployment }\end{array}$ & $\begin{array}{c}0,070 \\
(2,46)^{* *}\end{array}$ & $\begin{array}{c}0,070 \\
(2,44)^{* *}\end{array}$ & $\begin{array}{c}0,072 \\
(2,53)^{* *}\end{array}$ & $\begin{array}{c}-0,122 \\
(-2,25)^{* *}\end{array}$ & $\begin{array}{c}-0,142 \\
(-2,53)^{* *}\end{array}$ & $\begin{array}{c}-0,125 \\
(-2,30)^{* *}\end{array}$ \\
\hline Unemployment, age 55-65 & $\begin{array}{l}0,023 \\
(0,80)\end{array}$ & $\begin{array}{l}0,034 \\
(1,20)\end{array}$ & $\begin{array}{r}0,024 \\
(0,85)\end{array}$ & $\begin{array}{l}-0,068 \\
(-1,31)\end{array}$ & $\begin{array}{l}-0,010 \\
(-0,18)\end{array}$ & $\begin{array}{l}-0,059 \\
(-1,12)\end{array}$ \\
\hline $\begin{array}{l}\text { Change in unemployment, } \\
\text { age 55-65 }\end{array}$ & $\begin{array}{c}0,055 \\
(2,07)^{* *}\end{array}$ & $\begin{array}{l}0,041 \\
(1,56)\end{array}$ & $\begin{array}{c}0,054 \\
(2,02)^{* *}\end{array}$ & $\begin{array}{l}0,062 \\
(1,17)\end{array}$ & $\begin{array}{l}0,015 \\
(0,28)\end{array}$ & $\begin{array}{l}0,062 \\
(1,17)\end{array}$ \\
\hline Wage & $\begin{array}{l}-0,000 \\
(-0,78)\end{array}$ & $\begin{array}{l}-0,000 \\
(-1,01)\end{array}$ & $\begin{array}{l}-0,000 \\
(-0,77)\end{array}$ & $\begin{array}{c}0,000 \\
(5,70)^{* * *}\end{array}$ & $\begin{array}{c}0,000 \\
(6,08)^{* * *}\end{array}$ & $\begin{array}{c}0,000 \\
(5,73)^{* * *}\end{array}$ \\
\hline
\end{tabular}




\begin{tabular}{|c|c|c|c|c|c|c|}
\hline \multicolumn{7}{|l|}{ Crime } \\
\hline Criminal acts & --- & $\begin{array}{c}0,00 \\
(2,58)^{* * *}\end{array}$ & --- & --- & $\begin{array}{l}0,000 \\
(1,45)\end{array}$ & --- \\
\hline Change in Criminal acts & --- & $\begin{array}{l}-0,001 \\
(-1,11)\end{array}$ & --- & --- & $\begin{array}{c}-0,002 \\
(-1,94)^{*}\end{array}$ & --- \\
\hline Thefts & $\begin{array}{c}-0,000 \\
(-1,97)^{* *}\end{array}$ & --- & $\begin{array}{c}-0,000 \\
(-1,93)^{*}\end{array}$ & $\begin{array}{l}-0,000 \\
(-0,32)\end{array}$ & --- & $\begin{array}{l}-0,000 \\
(-0,19)\end{array}$ \\
\hline Change in thefts & $\begin{array}{l}-0,001 \\
(-1,63)\end{array}$ & --- & $\begin{array}{c}-0,001 \\
(-1,65)^{*}\end{array}$ & $\begin{array}{c}-0,005 \\
(-3,36)^{* * *}\end{array}$ & --- & $\begin{array}{c}-0,005 \\
(-3,26)^{* * *}\end{array}$ \\
\hline Violent crimes & $\begin{array}{c}0,000 \\
(3,00)^{* * *}\end{array}$ & --- & $\begin{array}{c}0,000 \\
(2,94)^{* * *}\end{array}$ & $\begin{array}{l}0,000 \\
(0,50)\end{array}$ & --- & $\begin{array}{r}0,000 \\
(0,38)\end{array}$ \\
\hline Change in violent crimes & $\begin{array}{l}-0,000 \\
(-0,93)\end{array}$ & --- & $\begin{array}{l}-0,000 \\
(-0,85)\end{array}$ & $\begin{array}{c}-0,001 \\
(-1,93)^{*}\end{array}$ & --- & $\begin{array}{c}-0,001 \\
(-1,87)^{*}\end{array}$ \\
\hline \multicolumn{7}{|l|}{ Infrastructure } \\
\hline Cars & $\begin{array}{l}-0,000 \\
(-1,63)\end{array}$ & $\begin{array}{c}-0,000 \\
(-2,24)^{* *}\end{array}$ & $\begin{array}{c}-0,000 \\
(-1,76)^{*}\end{array}$ & $\begin{array}{l}-0,000 \\
(-1,05)\end{array}$ & $\begin{array}{l}-0,000 \\
(-1,04)\end{array}$ & $\begin{array}{l}-0,000 \\
(-1,24)\end{array}$ \\
\hline Kindergarten & $\begin{array}{l}0,000 \\
(0,87)\end{array}$ & $\begin{array}{l}0,000 \\
(0,80)\end{array}$ & $\begin{array}{l}0,000 \\
(0,67)\end{array}$ & $\begin{array}{l}-0,000 \\
(-0,08)\end{array}$ & $\begin{array}{l}-0,000 \\
(-0,01)\end{array}$ & $\begin{array}{l}-0,000 \\
(-0,26)\end{array}$ \\
\hline Primary schools & $\begin{array}{l}-0,830 \\
(-0,33)\end{array}$ & $\begin{array}{l}-2,175 \\
(-0,86)\end{array}$ & $\begin{array}{l}-0,917 \\
(-0,36)\end{array}$ & $\begin{array}{c}-12,549 \\
(-2,62)^{* * *}\end{array}$ & $\begin{array}{c}-15,710 \\
(-3,04)^{* * *}\end{array}$ & $\begin{array}{c}-12,543 \\
(-2,62)^{* * *}\end{array}$ \\
\hline Secondary Schools & $\begin{array}{l}-3,415 \\
(-1,46)\end{array}$ & $\begin{array}{l}-1,727 \\
(-0,73)\end{array}$ & $\begin{array}{l}-3,142 \\
(-1,33)\end{array}$ & $\begin{array}{l}6,003 \\
(1,38)\end{array}$ & $\begin{array}{l}7,531 \\
(1,63)\end{array}$ & $\begin{array}{l}6,462 \\
(1,48)\end{array}$ \\
\hline Constant & $\begin{array}{c}0,051 \\
(3,58)^{* * *}\end{array}$ & $\begin{array}{c}0,046 \\
(3,19)^{* * *}\end{array}$ & $\begin{array}{c}0,044 \\
(3,02)^{* * *}\end{array}$ & $\begin{array}{c}0,041 \\
(1,77)^{*}\end{array}$ & $\begin{array}{c}0,028 \\
(1,11)\end{array}$ & $\begin{array}{l}0,036 \\
(1,49)\end{array}$ \\
\hline Election (year) & \multicolumn{6}{|c|}{ Dummy variable for each election \& year included } \\
\hline Wald $-\chi^{2}$ & 5843,86 & 5822,19 & 5839,98 & 3760,21 & 3807,38 & 3765,01 \\
\hline $\mathrm{R}^{2}$ & 0.79 & 0.79 & 0.79 & 0.87 & 0.87 & 0.87 \\
\hline Nobs & 1568 & 1568 & 1568 & 686 & 686 & 686 \\
\hline
\end{tabular}

Note: t-values in parantheses; ***, ** and * indicate statistical significance on the 1, 5 and 10 percent level, respectively (two-tailed test). 
Table 8: A heuristic summary of spatial determinants of right-wing and protest voting

\begin{tabular}{|c|c|c|c|c|c|c|c|c|c|c|}
\hline & NPD & DVU & REP & $\begin{array}{c}\text { Rechte } \\
\text { (total) }\end{array}$ & Schill & $\begin{array}{c}\text { Pro } \\
\text { DM/Schill }\end{array}$ & PDS & STATT & CDU & SPD \\
\hline $\begin{array}{l}\text { Immigrants and } \\
\text { immigration }\end{array}$ & & + & + & ++ & + & + & - & - & + & $-/+$ \\
\hline $\begin{array}{l}\text { Young native } \\
\text { population }\end{array}$ & & & & + & & & & & - & \\
\hline $\begin{array}{l}\text { Elderly native } \\
\text { population }\end{array}$ & $+/-$ & + & & + & & & - & & + & + \\
\hline Tertiary education & -- & -- & & & -- & & & -- & -- & \\
\hline Blue collar workers & & & ++ & ++ & & & + & - & -- & ++ \\
\hline $\begin{array}{l}\text { Bad housing } \\
\text { conditions }\end{array}$ & & & + & + & & $+/-$ & - & - & - & + \\
\hline Welfare reception & & $+/-$ & $-/+$ & ++ & - & - & $+/-$ & - & & $-/+$ \\
\hline Unemployment & ++ & + & $-/+$ & $-/+$ & $-/+$ & + & ++ & & & $+/-$ \\
\hline Youth unemployment & - & $+/-$ & $+/-$ & + & $+/-$ & & $-/+$ & & & \\
\hline $\begin{array}{l}\text { Unemployment of } \\
\text { elderly }\end{array}$ & & & + & & + & - & & & & + \\
\hline High wage jobs & & & & & & & & + & + & \\
\hline Criminal acts & - & + & $+/-$ & & & & + & - & - & + \\
\hline Thefts & & $-/+$ & - & & + & & -- & - & & ++ \\
\hline Violent crimes & & + & & & & & + & & - & \\
\hline Private transport & & + & & + & & + & & & & \\
\hline $\begin{array}{l}\text { Elementary and } \\
\text { primary education } \\
\text { facilities }\end{array}$ & & & & -- & & & & - & - & - \\
\hline $\begin{array}{l}\text { Secondary education } \\
\text { facilities }\end{array}$ & & & & & & & & & - & + \\
\hline
\end{tabular}

Note: “++”/”"” = qualitativley positive correlation; “--“"”-“ = qualitatively negative correlation; “+/-“ = mixed effect 


\section{References}

${ }^{1}$ F. Decker and F. Hartleb, 'Populism on Difficult Terrain: The Right- and Left-Wing Challenger Parties in the Federal Republic of Germany', German Politics, 16/4 (2007), pp. 434-454, at pp. 444-446.

${ }^{2}$ K. von Beyme, 'Right-Wing Extremism in Post-War Europe', West European Politics, 11 (1988), pp. 1-18.

${ }^{3}$ E. K. Scheuch and H. D. Klingemann, 'Theorie des Rechtsradikalismus in westlichen Industriegesellschaften', Hamburger Jahrbuch für Wirtschafts- und Gesellschaftspolitik, 12 (1967), pp. 11-19; H. D. Klingemann and F. U. Pappi, Politischer Radikalismus (Munich: Oldenbourg, 1972).

${ }^{4}$ H.-G. Betz, 'Rechtspopulismus: Ein internationaler Trend?', Aus Politik und Zeitgeschichte, 9-10/98 (1998), pp. 3-12; K. Arzheimer and M. Klein, 'Liberalismus, Rechtsradikalismus und Rechtspopulismus in Deutschland und Österreich. Bestandsaufnahme und Zukunftsszenarien', in: F. Plasser et al. (eds.), Wahlen und politische Einstellungen in Deutschland und Österreich (Frankfurt: Lang, 1999), pp. 31-63; A. Cole, 'Old Right or New Right? The Ideological Positioning of Parties of the Far Right', European Journal of Political Research, 44 (2005), pp. 203-230; E. Ivarsflaten, 'The Vulnerable Populist Right Parties: No Economic Realignment Fuelling their Electoral Success’, European Journal of Political Research, 44 (2005), pp. 465-492.

${ }^{5}$ F. Meijerink, C. Mudde and J. van Holsteyn, 'Right-Wing Extremism', Acta Politica, 33/2 (1998), pp. 165-178. ${ }^{6}$ For a concise overview see R. Rotte and M. Steininger, 'Sozioökonomische Determinanten rechtsextremistischer Wahlerfolge im vereinten Deutschland. "Republikaner“ und NPD bei den Europawahlen 1994 und 1999’, Schmollers Jahrbuch, 121/3 (2001), pp. 353-406.

${ }^{7}$ W. S. Robinson, 'Ecological Correlations and Behaviour of Individuals', American Sociological Review, 15 (1950), pp. 351-357.

${ }^{8}$ G. King, A Solution to the Ecological Inference Problem. Reconstructing Individual Behavior from Aggregate Data (Princeton: Princeton University Press, 1997), pp. 12-17; G. King, O. Rosen and M. A. Tanner, 'Information in Ecological Inference: An Introduction', in: G. King, O. Rosen and M. A. Tanner (eds.), Ecological Inference. New Methodological Strategies (Cambridge: Cambridge University Press, 2004), pp. 1-12. ${ }^{9}$ G. King, A Solution, pp. 8-34.

${ }^{10}$ R. F. Hamilton, Who Voted for Hitler? (Princeton: Princeton University Press, 1982); T. Childers, The Nazi Voter: The Social Foundations of Facism in Germany, 1919-1933 (Chapel Hill: University of North Carolina Press, 1983); J. W. Falter, 'Hat Arbeitslosigkeit tatsächlich den Aufstieg des Nationalsozialismus bewirkt?', Jahrbücher für Nationalökonomie und Statistik, 200/2 (1985), pp. 121-136; J. W. Falter, Hitlers Wähler (Munich: Beck, 1991).

11 B. Frey and H. Weck, ,Hat Arbeitslosigkeit den Aufstieg des Nationalsozialismus bewirkt?', Jahrbücher für Nationalökonomie und Statistik, 196/1 (1981), pp. 1-31.

${ }^{12}$ J. W. Falter, 'Hat Arbeitslosigkeit tatsächlich'.

${ }^{13}$ e.g. D. Bogue and E. J. Bogue, 'Ecological Correlation Reexamined: A Refutation of the Ecological Fallacy', in: G. A. Theodorson (ed.), Urban Patterns: Studies in Human Ecology (University Park: Pennsylvania State University Press, 1982), pp. 88-103.

${ }^{14}$ e.g. L. Goodman, 'Some Alternatives to Ecological Correlation', American Journal of Sociology, 64 (1959), pp. 610-624.

${ }^{15}$ e.g. W. H. Flanigan and N. Zingale, 'Alchemist's Gold: Inferring Individual Relationships from Aggregate Data’, Social Science History, 9 (1985), pp. 71-92; C. H. Achen and W. P. Shively, Cross-Level Inference (Chicago: University of Chicago Press, 1995).

${ }^{16}$ G. King, A Solution, pp. 5-6.

${ }^{17}$ In the examples for statistical analyses of voting behaviour given in G. King, O. Rosen and M. A. Tanner (eds.), Ecological Inference, which is the most recent and advanced technical publication on the ecological fallacy problem, there is no case in which coefficient significance poses any problem.

${ }^{18}$ G. Kirchgässner, 'Zur Erfassung des Einflusses der Wirtschaftslage auf das Wahlverhalten mit Hilfe von Wahlfunktionen’, in: Manfred Holler (ed.), Wahlanalyse (Munich: Tuduv, 1984), pp. 119-134, at p. 127.

${ }^{19}$ D. S. Voss, 'Using Ecological Inference for Contextual Research', in: G. King, O. Rosen and M. A. Tanner (eds.), Ecological Inference, pp. 69-96, at pp. 70-71.

${ }^{20}$ e.g. B. E. Lockerbie, 'Prospective Voting in Presidential Elections: 1956-1988', American Political Quarterly, 20/3 (1992), pp. 308-325; P. Nannestad and M. Paldam, 'The VP-Function: A Survey of the Literature on Vote and Popularity Functions after 25 years', Public Choice, 79/3-4 (1994), pp. 213-245; O. Borre and J. G. Aandersen, Voting and Political Attitudes in Denmark: A Study of the 1994 Election (Aarhus: Aarhus University Press, 1997); R. Johnston et al., 'Locating the Altruistic Voter: Context, Egocentric Voting, and Support for the Conservative Party in the 1997 General Election in England and Wales', Environment and Planning A, 32/4 (2000), pp. 673-694. 
21 C. Lüdemann, 'Kriminalitätsfurcht im urbanen Raum', Kölner Zeitschrift für Soziologie und Sozialpsychologie, 58/2 (2006), pp. 285-306.

${ }^{22}$ K. Torfs, 'Verschillen in Stemgedrag bij Gemeenteraadsverkiezingen en Socio-Economische Kenmerken van Gemeenten', Res Publica 33/2 (1991), pp. 205-227.

${ }^{23}$ W. Jagodzinski, J. Friedrichs, Jürgen and H. Dulmer, 'Urban Conflict and Voting Pattern: Some Tentative Generalizations from the Last State Election in Hamburg’, Res Publica 37/2 (1995), pp.177-188.

24 T. Faas and A. M. Wüst, 'The Schill Factor in the Hamburg State Election 2001', German Politics 11/2 (2002), pp.1-20.

25 T. Bijlsma and F. Koopmans, 'Voting for the Extreme Right in Amsterdam', Sociologische Gids 43/3 (1996), pp. 171-182.

${ }^{26}$ M. Lubbers and P. Scheepers, 'Individual and Contextual Characteristics of the German Extreme Right-Wing Vote in the 1990s: A Test of Complementary Theories’, European Journal of Political Research, 38 (2000), pp. 63-94.

${ }^{27}$ R. Rotte and M. Steininger, 'Sozioökonomische Determinanten'.

${ }^{28}$ J. W. Falter and M. Klein, Wer wählt rechts? Die Wähler und Anhänger rechtsextremistischer Parteien im vereinigten Deutschland (Munich: Beck, 1994); J. W. Falter and S. Schumann, "Die Republikaner“, in: P. Eisenmann and G. Hirscher (eds.), Die Entwicklung der Volksparteien im vereinten Deutschland (Munich: Verlag Bonn Aktuell, 1992), pp. 191-228; J. W. Falter and S. Schumann, 'Nichtwahl und Protestwahl: Zwei Seiten einer Medaille', Aus Politik und Zeitgeschichte, 11/93 (1993), pp. 36-49; F. U. Pappi, 'Die Republikaner im Parteiensystem der Bundesrepublik Deutschland', Aus Politik und Zeitgeschichte, 21/89 (1989), pp. 37-44.

${ }^{29}$ T. Faas and A. M. Wüst, 'The Schill Factor'.

${ }^{30}$ Ibid, pp. 15-17.

${ }^{31}$ F. Decker, 'Perspektiven des Rechtspopulismus in Deutschland am Beispiel der "Schill-Partei“, Aus Politik und Zeitgeschichte, 21/02 (2002), pp. 22-31.

32 Statistisches Landesamt Der Freien und Hansestadt Hamburg (ed.), Hamburg in Zahlen + Karten. Hamburger Stadtteilprofile 2000 (Hamburg: Statistisches Landesamt, 2000).

${ }^{33}$ S. Gapper, 'The Rise and Fall of Germany’s Party of Democratic Socialism', German Politics, 12/2 (2003), pp. 65-85.

${ }^{34}$ F. Decker and F. Hartleb, 'Populism on Difficult Terrain'; J. Olsen, 'The Merger of the PDS and WASG: From Eastern German Regional Party to National Left Party?, German Politics, 16/2 (2007), pp. 205-221.

${ }^{35}$ F. Decker and F. Harleb, 'Populism on Difficult Terrain', pp. 438-439.

${ }^{36}$ W. H. Greene, Econometric Analysis (New York: Macmillan, 1993), pp. 444-449. In our case, Hausman and Breusch-Pagan tests reveal that the random effects model performs better than a fixed effects or an OLS model.

${ }^{37}$ M. Golder, 'Explaining Variation in the Success of Extreme Right Parties in Western Europe', Comparative Political Studies, 36/4 (2003), pp. 432-466, at p.459.

${ }^{38}$ R. W. Jackman and K. Volpert, 'Conditions Favouring Parties of the Extreme Right in Western Europe', British Journal of Political Science, 26 (1996), pp. 501-521; M. Golder, 'Explaining Variation’.

${ }^{39}$ M. Lubbers and P. Scheepers, 'Individual and Contextual Characteristics'; H. Dülmer and M. Klein, 'Extreme Right-Wing Voting in Germany in a Multilevel Perspective: A Rejoinder to Lubbers and Scheepers', European Journal of Political Research, 44 (2005), pp. 243-263; M. Lubbers and P. Scheepers, 'A Puzzling Effect of Unemployment: A Reply to Dülmer and Klein’, European Journal of Political Research, 44 (2005), pp. 265268.

${ }^{40}$ T. Faas and A. M. Wüst, 'The Schill Factor', pp. 17-19; infratest dimap, Wahlreport: Bürgerschaftswahl Hamburg 2001 (Hamburg: infratest dimap, 2001); Forschungsgruppe Wahlen, Wahl zur Bürgerschaft Hamburg, 23. September 2001 (Mannheim: FGW, 24 September 2001); Forschungsgruppe Wahlen, Bürgerschaftswahl in Hamburg, 29. Februar 2004 (Mannheim: FGW, 1 March 2004).

41 J. W. Falter, 'Zur Psychographie der Wähler der Republikaner und der DVU. Probleme, Sorgen und Einstellungen', Politische Studien, 336 (1994), pp. 68-91; J. Billiet and H. De Witte, 'Attitudinal Dispositions to Vote for a "New“ Extreme Right-Wing Party: The Case of „Vlaams Blok“, European Journal of Political Research, 27/2 (1995), pp. 181-202; D. Thränhardt, 'The Political Uses of Xenophobia in England, France and Germany', Party Politics, 1/3 (1995), pp. 323-345; E. Fascher, 'Die politischen Erfolgsaussichten der 'Republikaner' in Deutschland', Zeitschrift für Parlamentsfragen, 28/1 (1997), pp. 21-29; C. Lüdemann, ,Kriminalitätsfurcht im urbanen Raum’, pp. 285-286. 